Illinois State University

ISU ReD: Research and eData

Theses and Dissertations

7-21-2014

\title{
Mckinney Vento Legislation: A Policy Analysis Of The Evolution Of Homeless Law In Illinois
}

Cathleen J. Weber

Illinois State University, cathyjweber63@yahoo.com

Follow this and additional works at: https://ir.library.illinoisstate.edu/etd

Part of the Educational Administration and Supervision Commons, and the Education Policy Commons

\section{Recommended Citation}

Weber, Cathleen J., "Mckinney Vento Legislation: A Policy Analysis Of The Evolution Of Homeless Law In Illinois" (2014). Theses and Dissertations. 243.

https://ir.library.illinoisstate.edu/etd/243

This Dissertation is brought to you for free and open access by ISU ReD: Research and eData. It has been accepted for inclusion in Theses and Dissertations by an authorized administrator of ISU ReD: Research and eData. For more information, please contact ISUReD@ilstu.edu. 


\title{
MCKINNEY VENTO LEGISLATION: A POLICY ANALYSIS OF THE EVOLUTION OF HOMELESS LAW IN ILLINOIS
}

\author{
Cathleen Wilder Weber
}

110 pages

December 2014

This policy analysis looks at the evolution of homeless education laws both through federal legislation and state laws. A policy analysis was utilized to show changes through the reauthorization of the McKinney-Vento Act.

One aspect of this analysis utilized qualitative data from four individual administrators in four central Illinois school districts. The qualitative data reviewed the training received by each administrator and the policies guiding their enrollment procedures.

Another aspect provided in this analysis is the changes established in response to court cases filed when school districts violated the provisions of the McKinney-Vento Act. The reauthorizations that followed each finding incorporated the court judgments.

Finally, recommendations for further study and analysis of the McKinney-Vento Act are provided. 
MCKINNEY VENTO LEGISLATION: A POLICY ANALYSIS

OF THE EVOLUTION OF HOMELESS LAW IN ILLINOIS

CATHLEEN WILDER WEBER

A Dissertation Submitted in Partial

Fulfillment of the Requirements for the Degree of

DOCTOR OF PHILOSOPHY

Department of Educational Administration and Foundations

ILLINOIS STATE UNIVERSITY

2014 
Copyright 2014 Cathleen Wilder Weber 
MCKINNEY VENTO LEGISLATION: A POLICY ANALYSIS

OF THE EVOLUTION OF HOMELESS LAW IN ILLINOIS

CATHLEEN WILDER WEBER

COMMITTEE MEMBERS:

Elizabeth T. Lugg, chair

Guy Banicki

Norm Durflinger

Neil Sappington 


\section{ACKNOWLEDGMENTS}

I would like to thank Elizabeth T. Lugg, Ph. D., JD for her continuous support and direction for the completion of this dissertation. Dr. Lugg reminded me that anything is possible with the right combination of effort, education, and support!

Thank you to Michael E. Wissmiller. I could not have completed the hours of reading without your willingness to drive!

Thank you to Maurine E. Merryfield, your dedication to the care of Will and Rachelle provided me with ample time to complete this project.

I dedicate this dissertation to my children, William F. Weber and Rachelle E. Weber. Throughout my journey, you were my inspiration!

C.J.W. 


\section{CONTENTS}

Page

ACKNOWLEDGMENTS $\quad$ i

$\begin{array}{ll}\text { CONTENTS } & \text { ii }\end{array}$

\section{CHAPTER}

I. THE PROBLEM AND ITS BACKGROUND 1

Statement of the Problem 1

II. REVIEW OF THE LITERATURE 4

Section 1: History of Homelessness and Relevant Policies in the United States

Section 2: Legal and Legislative History $\quad 10$

Common Law Laid the Ground Work $\quad 10$

Federal Legislation Followed 11

The McKinney Homeless Children and Youth Program 14

Chicago Class Action 1992

McKinney-Vento Homeless Assistance Act of 2001

Prohibition of Segregated Schools 21

Turning Good Law into Effective Education 22

Federal Funding in District of Columbia 24

Leave No Child Out 25

$\begin{array}{ll}\text { III. RESEARCH DESIGN } & 27\end{array}$

Statement of the Problem 27

Research Questions $\quad 27$

Significance of Study $\quad 28$

Limitations $\quad 28$

Methodology 28

IV. LEGISLATION, ADMINISTRATIVE PROCEDURES, AND PROTECTED CLASS 
Section 1: Legislation

Section 2: Administrative Procedures

McKinney-Vento 2002 Essential Provisions 36

Segregation \& School Selection 37

School Selection $\quad 40$

Records $\quad 40$

Enrollment 41

Dispute Resolution $\quad 42$

Transportation 43

Access to Comparable Services 43

Academic Achievement Standards 44

Local Liaisons $\quad 44$

Coordination 46

Section 3: Protected Class $\quad 47$

V. COURT CASES IMPACTING REAUTHORIZATION 49

VI. ADMINISTRATOR KNOWLEDGE AND APPLICATION 55

Introduction to a Qualitative Study on Administrator Knowledge 55

Results: Participant Profile $\quad 55$

Document Analysis $\quad 57$

Research Issue $\quad 57$

Research Question 1: What services are being offered to homeless students enrolled in public schools? 58

Housing $\quad 58$

School Supplies $\quad 60$

Counseling 61

Nutrition $\quad 63$

Medical 63

Research Question 2: What training do administrators have on the services available to homeless students? 65

Certification Programs 65

Regional Office of Education 66

Research Question 3: What challenges are school administrators facing with the increasing population of homeless students? 67

Identification $\quad 67$

$\begin{array}{ll}\text { Mobility } & 69\end{array}$

$\begin{array}{ll}\text { Relationships } & 70\end{array}$ 
Research Question 4: What are the implications for homeless student learning and local education leaders with the increase in homeless students?

Social

Emotional

Educational

Physical

75

Summary

VII. CONCLUSIONS, RECOMMENDATIONS, AND SUMMARY

Section 1: Conclusions and Implications

Section 2: Recommendations for Future Research

79

Section 3: Summary

REFERENCES

APPENDIX A: McKinney-Vento Education for Homeless Children and Youth Act of 2001

APPENDIX B: Chronological Listing of Legislation

106

APPENDIX C: Illinois Bill of Rights for the Homeless

108 


\section{CHAPTER I}

\section{THE PROBLEM AND ITS BACKGROUND}

\section{Statement of the Problem}

A major educational problem confronting the American education system is the education of homeless students. Although homelessness is not a new phenomenon in the United States, it has taken on a new light with the recent economic conditions. Although the United States is known as the Land of Opportunity, those opportunities are not equitably distributed across ethnicity, gender, or socio-economic groups. Thus, a wide variety of people have found themselves not only without adequate incomes to support themselves and their families, but without adequate housing (Weber \& Lugg, 2008).

The history of homelessness can be traced to the early settlers (Rossi, 1991). The

pilgrims that set out to find a new land arrived in the Americas without adequate nightly housing. As the population grew in the east, settlers continued to move west developing communities and establishing residency along the way. Homelessness at that time was literally lacking a house or shelter (Berkowitz, 2002). Merriam-Webster's online dictionary (2010) defines homeless as "having no home or permanent place of residence." The homeless definition evolves with the enactment of legislation to resolve the issue. The evolution of the definition will be explored throughout this analysis. Homeless youth have a variety of issues affecting their ability to succeed in school. It is difficult for children who are hungry, scared, and living in either temporary 
housing or inadequate housing to concentrate on the elements of school. Research indicates homeless youth are absent from school more often than students that have a fixed residency (Weber \& Lugg, 2008). Qualitative research has been conducted to reveal counselor opinions of enrollment procedures and services available to homeless youth (Walsh \& Buckley, 1994). Another example of qualitative research was the Weber (2009) study completed on the enrollment procedures and services offered to homeless youth in four central Illinois schools.

The continuous economic struggle across the nation has broadened the need for educators and legislators to look at the needs of homeless students and their families. Information will be given to show how this population grew and changed over a few decades in the nineteenth century. Many people do not understand the relevance of homelessness to education. Homeless youth are more likely to change schools, be absent, need and/or receive special education services due to a lack of consistent education within a single school system, and experience health related issues (both physical and mental) (Rossi, 1991; Berkowitz, 2002; O’Brien, 2008; Lagana \& Hubley, 2010). Suffice it to say that students living without a fixed night time residency struggle academically.

One of the most difficult issues facing the education of homeless students is the definition of homeless. Today, the McKinney-Vento act defines homeless children and youth as "individuals who lack a fixed, regular, and adequate nighttime residence" (United States Department of Education, 2004).

Since 1987 and the enactment of the Education for Homeless Children and Youth Program (EHCY) as Title VII, Subtitle B of The Stewart B. McKinney Homeless Assistance Act (McKinney Vento Act) legislators have revamped and reauthorized 
provisions of the Act to assist homeless youth. Court cases filed when homeless youth have been denied educational opportunities or provided with inferior education as compared to students with a fixed residence drove the changes and reauthorization provisions. However, these laws have been enacted without ensuring the effectiveness of the provisions. 


\section{CHAPTER II}

\section{REVIEW OF THE LITERATURE}

\section{Section 1: History of Homelessness and Relevant Policies in the United States}

Throughout history, inequities in social status have existed that not only result in inadequate housing, but also attribute to the social structure (system) within the educational system. In From Poor Law to Welfare State (1994), Walter Trattner provides a comprehensive account of the contributions that have led to the current social structure in America. Trattner (1994) states, "The basic tenets and programs of any social welfare system reflect the values of the society in which the system functions" (p. 1). Trattner continues by relating historical events from ancient Greek and Roman philosophers through present day. The common thread throughout history is the "more blessed to give than to receive" (Trattner, 1994, p. 1). He also points out how Jewish doctrine supports "the duty of giving...the right of those in need to receive" (Trattner, 1994, p. 2). The ability of society to give and recognize those that are in need has spurred policies that try to implement social justice. Although this policy analysis will only look at American policy on educating homeless, it is important to note that this issue existed prior to the establishment of the Americas.

American policies originated from European colonization. Reviewing the history from England provides a foundation for the evolution of American policy. During the late fifteenth and sixteenth centuries in England, a set of policies were enacted. The first law 
was a 1592 statue to oversee "those in economic distress" and Poor Law of 1601, referred to as the Elizabethan Poor Law. Trattner (1994) states the thirteen colonies and later the Union states utilized these two laws as a foundation.

Trattner (1994) continues the history of social evolution in America by pointing out colonial settlers had needs. “...need was in the order of things, a natural and inevitable part of the human condition. The poor, mere pawns in a divinely destined universe and hence not responsible for their condition, were always present-in America as elsewhere" (Trattner, 1994, p. 17). Again, citizens utilized British policy to provide assistance to the needy. For example, in 1701 the colonial treasury reimbursed local funding for relief given to "unsettled persons" (Trattner, 1994, p. 23). "Unsettled persons" were defined as "people who if sent away, would endanger other communities" (Trattner, 1994, p. 23). Trattner indicates the segregation of Native Americans to reservations and the forced immigration of African slaves created another aspect to homelessness and poverty. Both groups were forced to live in unwanted lands or undesirable circumstances.

For individuals suffering from mental conditions, there were only two options, the Pennsylvania Hospital (1756) and Williamsburg, Virginia (1773) (Trattner, 1994, p. 25). Mental illness was viewed as an economic and social condition. The care of these individuals was a burden to society. As stated by Trattner (1994):

In the American colonies, where natural resources were abundant and labor was scarce, human life was held in esteem; the wisdom of providing for the poor was rarely, if ever, seriously challenged. On the contrary, the colonials were more interested in providing good treatment 
for the poor than they were in economizing on welfare costs. (Trattner, p.

Colonial society relied on all members of the community to be productive. Survival of the entire community required ever person to contribute in some way. The economically disadvantaged were essential in providing labor to land owners.

After the civil war, changes in perceptions of the poor and the purpose of social welfare began to unfold, specifically, the age of charity organizations or "scientific charity" (Trattner, 1994). Prior to the war, women did not have a public voice in social matters. During the war, woman worked to provide needed sanitation and personal hygiene of the soldiers. Women were also needed to assist near the battle field in make shift hospitals. By the end of the war, these women had developed a new self-image. After experiencing this new found independence, women that performed duties to assist with the war found it difficult to return to the domestic responsibilities they performed prior to the war. These women developed a new role in society. The men returned from the war to work where women had assisted during the war. This left the women time to assist in resolving public concerns. Female contributions to bridge the gap between the social classes lead to social welfare reform. One of these concerns was providing social welfare to the poor and needy in the community.

The sudden social change for oppressed African slaves impacted the entire nation. Being uneducated and ill prepared for their new freedom; a new wave of people discovered themselves unemployed and homeless. The new unsettled group meandered throughout the South looking for jobs and assistance. 
In 1865, before the end of the civil war, the Bureau of Refugees, Freedmen, and Abandoned Lands was established by Congress as the first welfare agency. This agency was inexistence for six years and was commonly known as the Freedman Bureau. The function of the Freedman Bureau was to assist blacks in their transition from slavery to freedom. Although this Bureau provided numerous services to blacks, importance should be given to the Bureau role in establishing black schools and providing financial aid for schools. This was one of the first steps toward social justice and homeless assistance in education. The creation of separate schools and the later findings that these separate institutions were not equal will be essential in homeless policy of the $20^{\text {th }}$ Century. This also created different levels of poverty and the feelings of inferior status between racial groups (Trattner, 1994). Trattner (1994) sites:

William Graham Sumner, the Yale professor and social Darwinist, was appalled by the "unlimited supply of reformers and would-be managers of society" he saw around him. Such conditions, he and others were certain, only led to waste, inefficiency, and above all, demoralization of the needy (p. 93).

The demoralization proved to be historic. The waste and inefficiency of the charitable organizations led to the reform movement known as "scientific charity" (pg. 95). Supporters wanted charity to be more organized, rational and efficient (Trattner, 1994). In essence, the supporters of scientific charity wanted to begin sorting the worthy recipients from the undeserving. By reforming the way relief was distributed organizers were able to keep records and eliminate "fraud, inefficiency, and duplicity" (Trattner, 1994). This began the separation of the deserving and undeserving poor. The entire 
society was moving toward industrialization and this was a reflection of that movement. In addition the Freedman Bureau led to data collection, research, and even literature on the poor in America. The research centered on involuntary unemployment, industrial accidents, and low wages (Trattner, 1994).

The twentieth century was significant in identifying the child welfare reform. Robert Hunter (1904) wrote in Poverty, as cited by Trattner (1994), "Poverty degrades all men who struggle under its yoke, but the poverty which oppresses childhood is a monstrous and unnatural thing, for it denies the child growth, development, strength; it robs the child of the present and curses the man of the future" (p. 112). Once again, society is distinguishing between those that deserve assistance and those that do not. President Franklin D. Roosevelt supported alleviating poverty and narrowing the socioeconomic gap thirty years later when he stated: "The destiny of American youth is the destiny of America" (Trattner, 1994, p. 112). The literature produced during this period changed America's view on evolution, human development, and social reform ultimately leading to raising the status of children in society (Trattner, 1994).

The industrial revolution marked additional education requirements from society. Factories needed a large work force; however, that population was not educated to streamline productivity. Hence, the manufacturers pressured politicians to establish minimum standards and levels of education. This was the beginning of the standards based curriculum and assessment reform. These standards and assessments were not applied to all children being educated. The Freedman Bureau had established separate schools for freed men and woman, but did not provide an equal education. The separation of educational institutions widened the achievement gap of poor students and the affluent 
class. The government did not apply measures to curb the social issues affecting the education of indigent families or rectify the causes of poverty. The establishment settlement homes did little to address the educational or social issues (Trattner, 1994).

The judicial system began evolving policy through court cases. These court cases will be discussed in the policy section and in Chapter V, but it is important to note here that even with the Court support, social reform evolved slowly and often digressed. In Conflict of Interests: the Politics of American Education, Spring (2004) writes, “...most judges avoid basing judicial decisions on social science evidence" (p. 211). Until the evidence presented regarding separation of educational institutions was addressed by the courts, education oppressed most people in poverty. Only when the courts determined separate was not inherently equal for all populations (African Americans, Native Americans, and mentally handicapped) did sociologist and educators join together to promote social justice through education. The desegregation movement transitioned social justice to the forefront for all races, gaining equal access to both education and careers. With the courts providing the legal application for social justice, it was interesting that educators tried to separate homeless students from their peers. Since homelessness existed throughout the evolution of American society the separation of those students from traditional students allowed society to digress back to utilizing education as a way to oppress people of poverty.

The issue of homelessness as a form of oppression moved to the forefront of the national agenda during the economic downturn of the 1980s (Rossi, 1991). Throughout most of the twentieth century, society recognized transient males as homeless; "hobos" camped out along the railways. Males continued to comprise the majority of the homeless 
population through the 1960's. Although society viewed the majority of homeless people as adult males, political leaders began acknowledging the need for educating homeless children as early as the 1960's even though it took another 20 years for substantive legislation to be passed to protect some of the weakest of American citizens; homeless children (Rossi, 1991).

Additional organizations have been established to address the needs of the homeless population and to continue social aid to those afflicted by a wide variety of circumstances; economic hardship, natural disaster, and other reasons. Ultimately, social reform will never end until society eliminates the causes of poverty.

\section{Section 2: Legal and Legislative History}

\section{Common Law Laid the Ground Work}

Many court cases and legislative acts have guided society toward the current policies impacting homeless students, starting with basic desegregation cases. The issue of separate but equal schools was upheld in 1849 with the Roberts v. City of Boston, 59 Mass. 198 (1849). This case involved African Americans filing suit against the mandated racially segregated education system. Roberts started the line of jurisprudence which lasted over 100 years, framing the issue of "equal education" being one of access rather than parity. So long as children had "access" to public schooling, the court did not find a legal mandate that the actual schools be identical in form or substance.

The court case most cited as the foundation for overturning the concept of

"separate but equal," the ultimate desegregation of schools, and extending the concept of “stigmatizing segregation" to handicapped and ultimately homeless youth is Oliver L. Brown et.al. v. the Board of Education of Topeka (KS) et.al, 347 U.S. 483, 74 S.Ct. 686, 
98 L.Ed. 873 (1954). The legal team originally led by Charles H. Houston, and later by Thurgood Marshall, set in motion with the previous unheard of reliance on psychological testimony, a legal basis demanding the end of racial segregation both in public facilities and schools. They were so successful that in its opinion, the Supreme Court stated that "separate is inherently" unequal; to segregate and separate children because of race (and ultimately handicap) created a stigmatization which that child would perhaps never overcome. This court case is sited when school districts try to separate children for any reason. The rationale of the Court in this 1954 case continues to drive the legal basis for desegregating homeless educational facilities (Berkowitz, 11). As early as 2000, the National Law Center on Homelessness and Poverty began opposing separate schools for homeless youth (Berkowitz, 7). Opponents proclaimed “... that separate schools provide an inadequate public education to the children they work to serve... kids are not getting the same education they would get in a regular school environment" (Berkowitz, 7).

\section{Federal Legislation Followed}

Just prior to his death on October 31, 1963, President John F. Kennedy signed the Community Mental Health Act. This Act was designed to provide federal funding for the construction of community-based treatment centers. However, the program was never adequately funded due to the Vietnam War and the economic crisis that ensued during this time period. Many mental health patients were released without adequate skills to provide for themselves. Soldiers returning from the war lacked employment opportunities. Both of these scenarios increased the visibility of the homeless population.

President Lyndon B. Johnson pushed congress to enact the Elementary and Secondary Education Act of 1965 (ESEA) (P.L. 89-10, 79 Stat. 27, 20 U.S.C. Ch. 70). 
As a former educator, President Johnson believed the "War on Poverty" could only be won with equal access for all children to education. This federal education bill proved to be the most expansive education legislation and was a foundation for current policy. The ESEA was intended to be a major weapon in the fight against racial and socio-economic inequality across the country by earmarking funds to provide categorical aid to local education agencies to "combat social and economic problems" (Wong, 16 ND J. L. Ethics \& Pub Poly 421, at 424). The attempt, however, to position the ESEA as a cornerstone in Johnson's "Great Society" was somewhat stymied by the United States Supreme Court in its decisions in San Antonio v Rodriquez, 411 U.S. 1, 93 S.Ct. 1278, 36 L.Ed.2d 16 (1972) when the Court refused to find either a fundamental right in education or define "poverty" as a suspect class, either of which would have forced the court to use strict scrutiny when reviewing public education funding.

President Jimmy Carter continued the federal legislation of mental health with the homeless population by enacting the Mental Health Systems Act of 1980. During President Carter's message to Congress, he relayed several purposes including:

"To assist the chronically mentally ill to function effectively outside of institutions, the Departments of Health, Education, and Welfare and Housing and Urban Development have initiated a joint demonstration project which provides both housing and support services." (Jimmy Carter)

America was working to resolve social issues, education equity, and class issues. All three branches of the government participated in the evolution. 
Ten years after the San Antonio v Rodriquez, the Court handed down a stunning blow in its decision in Plyler $v$ Doe, 457 U.S. 202, 102 S.Ct. 2382, 72 L.Ed. 786 (1982) to those who would have liked to preclude children of illegal immigrants from benefiting from state education funding or federal categorical aid. In Plyler, the Court found that undocumented aliens were "persons" under the Fourteenth Amendment to the Federal Constitution and as such is guaranteed due process and equal access to the law. As such, the Court continued, "The Fourteenth Amendment affords homeless children the same protection as alien children and all children of every race, color, or nationality." (Berkowitz, 11) Withholding educational opportunities would be an "ineffectual and unjust way of deterring a parent" (Berkowitz, 11). Thus, the child should not be punished for parent actions. The Supreme Court determined that all children whether citizens or aliens were entitled to an education to prevent them from further racial discrimination.

This court decision brought to light the dilemma of citizenship as a barrier to enrollment in public school. Schwartz and Day in their book, Illinois Law in the School Office: The Essential Desk Reference, provide a concise summary of the court's opinion:

\subsection{Illegal Aliens}

The immigration status of parents and children has no bearing on the right of children to enroll in school. As such, school districts may not question a child's immigration status as part of the enrollment process. Furthermore, a school district may not, as part of a residency inquiry, require that parents or adult caretakers provide either a Visa, "Green Card," Illinois driver's license, a state identification card or other documents that require a Social Security number. (2013, pg. 28)

In the 1970'and 1980's, homelessness changed. Homeless individuals began living in public space and so were no longer invisible. This changed society's response to homeless individuals because those individuals could no longer be ignored. Moreover, 
with the economic downturn, these individuals were now a diverse group stemming from a wide range of demographics. Previous stereotypes had portrayed homeless individuals as being male, middle-aged, white alcoholic (O'Brien, 2). Now this had changed and the homeless included minorities, women and children; in some instances entire families. "According to a 1999 study, approximately forty percent of the homeless population [was] comprised of single mothers and their children, representing one of the fastest growing homeless groups" (O’Leary, 514). In 1984 the United States Department of Housing and Urban Development (HUD) estimated that fewer than 350,000 people across America were homeless. By 2001 the Children's Defense Fund estimated that 850,000 children and youth were homeless. (O'Leary, 514). The increased number and visibility of the homeless population spurred legislation.

\section{The McKinney Homeless Children and Youth Program}

Congress acted in 1987 with the passing of the Education for Homeless Children and Youth Program (EHCY) as Title VII, Subtitle B of The Stewart B. McKinney Homeless Assistance Act (McKinney Act). Under this act states are provided funding through the Department of Education to ensure compliance with the provisions of the Act. The goal of the McKinney Act was to eliminate barriers (both legal and practical) in the education of homeless children. Congress amended the Act in 1990, 1992, and 1994.

In the 1990 amendment, enacted to strengthen the provisions of the McKinney Act, the EHCY mandated that "each State educational agency shall ensure that each child of a homeless individual and each homeless youth has equal access to the same free, appropriate public education, including a public preschool education, as provided to other children and youth" (O’Leary, 3). This meant that now just letting homeless children in 
the door was not enough. Schools were expected to provide them an "equal education" including assurances that they could meet the standards set at the National Education Summit of 1989 led by then-President George H. W. Bush and then-Arkansas Governor William J. Clinton.

Another requirement under the 1990 amendment was that every state was required to appoint a State Coordinator for Homeless Education who was responsible for the understanding of and compliance with the McKinney-Vento Homeless Assistance Act. For ease of administration, these State Coordinators formed regional groups to aid with their tasks. Illinois is part of the North Central groups along with Indiana, Wisconsin, Michigan, Kentucky, and Ohio.

Congress reauthorized the McKinney Act in 1994 with special directions to the local education agencies (LEA) in each state. The LEA's could utilize funds to provide an assortment of direct services to the children that were homeless. Decisions were to be made on a case-by-case basis using "the best interest of the student" as the standard to determine which services were appropriate. One size no longer fit all. Along with the funding, the LEA was required to eliminate barriers to enrollment and retention. Those barriers included: lack of transportation, immunization requirements, residency requirements, school records or any other document required for registration and continued educational services. Previous McKinney language appropriated a fixed sum of $\$ 50$ million to implement the Act. In 1994 the language was changed to "such sums as may be necessary" (O'Leary, 3).

Even with the strengthened language, lack of funding and noncompliance by the states continued to prevent the wholesale integration of homeless students as was 
envisioned by the drafters of the McKinney Act. For example, in 1998, in Lampkin v. District of Columbia, 27 F. 3d 605 (D.C. Cir. 1994), cert. denied, 513 U.S. 1016 (1994), on remand, 879 F. Supp. 116 (D.D.C. 1995), dissolving injunction, 886 F. supp. 56 (D.D.C. 1995), when the District of Columbia decided that providing transportation would prove to be too costly, it withdrew completely from the program. The ability to do this was possible because for all of its provisions, the McKinney Act as it applied to school children was simply a form of categorical aid. Since education is a power reserved to the state, if the federal government wishes to further its agenda as it pertains to education it must enter into a contract with each individual state to provide federal money in return for compliance with certain terms by the state; a small abdication of the state's constitutional rights as it were. As with any contract, however, categorical aid contracts can be broken. In Lampkin, the Supreme Court denied certiorari, leaving the ruling of the District court in tact. The district court ruled that the federal government cannot enforce penalties on states or LEA's for not abiding by the McKinney Act. However, the federal government can withhold the funds authorized to the state or LEA for programs provided for in the Act. With nothing to bar its action, the District of Columbia removed provisions for transportation of homeless youth to their schools stating the cost of implementing the provisions was prohibitive with regard to the revenue received from the federal government $(\mathrm{Na}, 12)$. The federal government stopped all federal funds to the District of Columbia (Na, $12 \&$ Ableidinger, 5). Later in this research, the District of Columbia reverses the decision to transport students due to funding (see Federal Funding in the District of Columbia). 


\section{Chicago Class Action 1992}

In 1992, a class action lawsuit against the Chicago Public Schools provided the necessary drive to change Illinois law. Salazar v. Edwards provided the foundation for not only changes to Illinois legislation, but eventually federal statue.

In Salazar v. Edwards, the plaintiffs (all homeless children between three years of age and twenty living in Chicago, not attending private or parochial schools, and their parents - also homeless and living in Chicago) alleged the defendants (Illinois State Board of Education, the Illinois Coordinator for Homeless Children and Youth, the State Superintendent of Education, the Chicago School Board, and the Chicago School Reform Board of Trustees) practices and policies violated the plaintiffs due process, the Illinois Constitution, and a variety of Illinois statutes.

The plaintiffs claimed homeless children were typically excluded from enrolling in their school of origin, required to provide excessive transfer documents, denied transportation, ignored parent desires, and withheld educational opportunities for weeks. The defendants also failed to implement policies to prevent isolation or stigmatization of homeless youth (Malone, 2006).

The settlement agreement reached in 1996 provided for policies and procedures for enrollment, transferring, and sustaining school attendance. Barriers to enrollment were eliminated by establishing new procedures (Malone).

The City violated the Consent decree and was issued an independent monitor in August 1999. The monitor was required to provide extensive reporting, provide families with notice of their rights and dispute resolution practices, revise written policies, liaisons designed in each school, and allocate public transportation passes (Malone). All of these 
provisions add in the development of the McKinney-Vento Homeless Assistance Act of 2001.

\section{McKinney-Vento Homeless Assistance Act of 2001}

Representative Judy Biggert (R-IL 13) introduced legislation in September 1999 to strengthen the McKinney Act. Her proposals were modeled after The Illinois Education for Homeless Children Act (enacted in 1995) which is regarded as "the most comprehensive and far-reaching legislation addressing the needs of homeless children" (O’Leary, 3). It was passed as the McKinney-Vento Homeless Assistance Act of 2001, a reauthorization of the McKinney Act utilizing the language from Illinois. The definitions outlined in the Illinois Act are still utilized today. In addition, Congress directed HUD to collect data regarding homeless persons in the United States (O'Brien, 5). Another significant contributor to the reauthorization of the 2001 Act was the authorization of the No Child Left Behind Act of 2001.

The 2001 bill Biggert proposed clarified the definition of homeless borrowing heavily from the definition included in the Illinois statute. Today, the McKinney-Vento act defines homeless children and youth as "individuals who lack a fixed, regular, and adequate nighttime residence." This term includes (as taken from Education for Homeless Children and Youth Program: Title VII-B of the McKinney-Vento Homeless Assistance Act, as amended by the No Child Left Behind Act of 2001, Non-Regulatory Guidance, United States Department of Education, Washington, D.C., July 2004):

○ Children and youth who are:

- sharing the housing of other persons due to loss of housing, economic hardship, or a similar reason (sometimes referred to as "doubled-up");

- living in motels, hotels, trailer parks, or camping grounds due to lack of alternative adequate accommodation; 
- living in emergency or transitional shelters;

- abandoned in hospitals; or

- awaiting foster care placement

- Children and youth who have a primary nighttime residence that is a public or private place not designed for, or ordinarily used as, a regular sleeping accommodation for human beings;

- Children and youth who are living in cars, parks, public spaces, abandoned buildings, substandard housing, bus or train stations, or similar settings; and

- Migratory children who qualify as homeless because they are living in circumstances described above.

The legislation also provided for choice of schools, transportation to the school of origin, dispute resolution, and consequences for violating the Act. Specifically, it differed from the predecessor program in the following ways:

- Express prohibition against segregating homeless students from the general student population

- Requirement for transportation to and from the homeless students' school of origin

○ Immediate school enrollment requirement; if in doubt the child must be enrolled pending an investigation

- Changes in "best interest" determination which keeps the child in the school of origin if at all possible unless the parent or guardian does not wish that placement

- Local liaison in all school districts regardless of whether that district receives McKinney-Vento funding

$\circ$ New sub-grant requirements

Because of the inherent instability of being homeless, it is imperative that, to insure academic and social growth, that homeless children have stability in their school 
environment, whence the preference to maintain the homeless child in his or her "original" school unless it is determined that such is not in the "best interest" of the student or is against the wishes of the child's parent or guardian. Any placement determination, whether in the school or origin, the school requested by the parent or guardian, or another school chosen for sound reasons by the LEA, must be studentcentered and made on a case-by-case basis. Factors that may be considered by the LEA when making such a decision include the age of the student, the distance or commute and any impact such distance may have on the student's academic achievement, the personal safety of the student, whether the student is currently or should be receiving special services, the anticipated length of the student's stay in his or her temporary accommodation, and the number of days or months remaining in the school year.

In the case of a dispute, the LEA must enroll the child in the school requested by the parent or guardian pending further investigation. It is critical that students NOT be kept out of school during the appeal because such a disruption would make a bad situation even worse. Immediately enrolling the student in the school of choice provides needed stability and avoids any stigmatization of the homeless student. Should the event arise that, given a critical mass of homeless students, that services could be more effectively provided in an alternate placement, such as an evening tutoring session at the homeless shelter, great pains must be taken to avoid stigmatization of the homeless students.

As regarding transportation, if the student remains within the same LEA as his or her school or origin, then the LEA of the school of origin must arrange for the transportation of the homeless student. Should the student move into another LEA, then 
the new LEA and the LEA from the student's school of origin must collaborate to ensure that transportation is provided for the homeless student. This is another example of how ALL barriers must be broken down so that homeless children are guaranteed access to an equal educational program.

\section{Prohibition of Segregated Schools}

In 1987, the original legislation provided guidelines for local education associations (LEAs) to overcome the enrollment barriers for homeless youth. Many districts felt frustration with these new guidelines. In response to the guidelines nontraditional schools appeared across the country. Federal legislators modified the provisions of the McKinney Vento Homeless Act requiring states to "adopt policies and practices to ensure that homeless children and youth are not isolated or stigmatized" (Larson, 2002). Before receiving federal funding for educating homeless youth, states were required to submit a state plan outlining the strategies to be utilized to minimize barriers to enrollment and ensure the academic success of homeless youth.

Isolating homeless youth in education centers entirely focusing on homeless youth education violates the Act. Several court cases throughout history support the "separate is inherently" unequal findings. Those cases include Oliver L. Brown et.al. v. the Board of Education of Topeka (KS) et.al, 347 U.S. 483, 74 S.Ct. 686, 98 L.Ed. 873 (1954); San Antonio v Rodriquez, 411 U.S. 1, 93 S.Ct. 1278, 36 L.Ed.2d 16 (1972); and Plyler v Doe, 457 U.S. 202, 102 S.Ct. 2382, 72 L.Ed. 786 (1982). In Brown et.al, the Court ended racial segregation of schools (Berkowitz, 2002, p. 11). In San Antonio v Rodriquez, the court refused to define "poverty" as a suspect class (Berkowitz, 2002, p. 11). However, ten years later in Plyler v Doe, the Court continued, "The Fourteenth Amendment affords 
homeless children the same protection as alien children and all children of every race, color, or nationality" (Berkowitz, 2002, p. 11). Opponents of separate homeless education facilities utilize these three cases to promote the end of homeless segregation from traditional students.

The Thomas J. Pappas School is one well known homeless school located in Phoenix, Arizona. In 2000, Pappas Schools indicated their curriculum did not adhere to the Arizona Academic Standards and students at Pappas were not given the opportunity to learn these nine standards (English Language Arts/literature, mathematics, arts, technology, physical education, health, science, social studies, \& native/foreign language) (Arizona Department of Education, 2014). Thus, the education offered was not equitable to the educational standards for students in a traditional setting. Enrollment in the Pappas School is voluntary; however, opponents of the Pappas School stress that homeless families may not know the guidelines for enrolling their child in the school of origin. The 2001 reauthorization strictly prohibits federal funds for separate schools, but granted exception for Pappas and a select group of schools that were in existence prior to the reauthorization (Larson, 2002).

\section{Turning Good Law into Effective Education}

Per the provisions of the McKinney Vento Homeless Act, all states must submit a plan outlying the state guidelines for fulfilling the federal requirements. In the spring of 2004, authors John Wong, Amy Salomon, Lynda Thistle Elliott, Louis Tallarita, and Shelley Reed submitted a comprehensive article to the Georgetown Journal on Poverty Law \& Policy summarizing the efforts made in Connecticut, Rhode Island, New Hampshire, and Maine. The article provides not only a historical foundation for the Act, 
but also outlines the efforts implemented in the four New England states to assist homeless youth. These states have focused efforts to identify homeless children and increase overall knowledge to protect the legal rights of homeless youth, including all related needs of the homeless children and their families (Wong et al, 2004).

Connecticut established the Liaisons Online Unified Information System ("LOUIS") to assist LEAs. LOUIS is a data collection and evaluation system designed to be innovative and flexible. This tracking system provides a detailed picture of the local activities implemented to meet the needs of homeless children and youth. The results of the data collected indicate a reduction in enrollment delays. LEAs reported focusing on providing the necessary supplies for students to be successful in school and coordinating activities with tutoring and homework assistance with local shelters. Unfortunately, the LOUIS system was unable to track student achievement. Homelessness in not identified on student records, thus examining standard test scores or report cards proved to be timeconsuming (Wong et al., 2004).

The LOUIS system assists Connecticut educators and community organizations in identifying homeless children and youth. The system also points out the limitations of LEAs in tracking student achievement over time. However, the establishment of the New England Coordinators of Homeless Education Network and the New England Comprehensive Assistance Center has increased local awareness and commitment to acknowledge the need for additional funding and tracking of homeless youth (Wong et al., 2004). 


\section{Federal Funding in District of Columbia}

In 1998, the District of Columbia reviewed the cost of transportation to the school of origin for homeless students. This review was in response to the Lampkin case. The District of Columbia withdrew completely from federal funding of the McKinney Vento Homeless Act after Lampkin v. District of Columbia, 27 F. 3d 605 (D.C. Cir. 1994), cert. denied, 513 U.S. 1016 (1994), on remand, 879 F. Supp. 116 (D.D.C. 1995), dissolving injunction, 886 F. supp. 56 (D.D.C. 1995). The District of Columbia legislators and school officials determined the funding was not adequate from the federal government for them to continue transporting students to their school of origin. This decision also included forfeiting all federal funding for homeless youth as appropriated with the McKinney Vento legislation and reauthorization legislation. However, on January 17, 2006, the District of Columbia Board of Education (BOE) requested Clifford Janey (superintendent) to apply for McKinney Vento Homeless funds. Support from the Washington Legal Clinic for the Homeless and the National Law Center on Homelessness and Poverty worked diligently for almost a decade to alter District of Columbia BOE member's opinions of the funding. By combining the funds set aside to aid homeless youth after the Lampkin decision with new federal funding, the district would double the available funding for a variety of services, including transportation, tutoring services, enrichment activities and other related services for homeless students (Slater, 2006). The funding issues faced by all school districts have forced opponents to the transportation requirement of the McKinney Vento Homeless Act to reconsider utilizing federal funds. In addition, this new request by the District of Columbia 
reinforces the financial assistance districts need to provide the appropriate services to homeless students.

\section{Leave No Child Out}

In the spring of 2008, Derek Black reviewed homelessness in his Howard Law Journal article titled Education Law Mini-Symposium: Leave No Child Out: An Introduction to Homelessness, Joblessness, and Bullying in America's Schools. Black reiterates the findings of Jennifer $\mathrm{Na}$ from her 2008 article, indicating her research “... sheds much needed light on a student population that is often unseen: homeless children" (Black, 2008, p. 3). He continues with "Her analysis goes to the very core of homeless student policies, questioning whether our legislative rhetoric matches our legislative will... the federal government's actual effort to support homeless children amounts to little more than window dressing" (Black, 2008, p. 3). Black and Na agree the McKinney Vento Homeless Act identifies the risks and barriers homeless children face in education, but fails to provide the funding necessary to effectively educate homeless students. Na points out "if states were actually forced to comply with the relevant legislation, most would simply return the federal funds" (Black, 2008, p. 3). Black concludes with “... but fifty years after Brown v. Board of Education and after at least twenty-seven plaintiff victories in state based litigation, these comments [homeless youth interviewed by Na] show us we are still leaving too many children behind" (Black, 2008, p. 3). Both Black and $\mathrm{Na}$ are calling for significant funding changes to adequately address homeless children education in America.

The increase in funding is only one of the three issues raised by $\mathrm{Na}$. $\mathrm{Na}$ lists "lack of guidance and careless federal monitoring" and "states' and school districts' opt-out 
option" as the other two issues. The first issue of "lack of guidance and careless federal monitoring" relates to the lack of valid federal accountability and reporting $(\mathrm{Na}, 2008, \mathrm{p}$. 10). The actually number of students experiencing homelessness is unknown. The mobility of the student and their family presents accounting difficulties, and no data base or recording system has been established for all LEAs to report homeless student data. Legislators can claim they are reducing the barriers to enrolling homeless youth, but who are the homeless? Where are they located? No data is available to determine if homeless youth are being identified and enrolled without delay.

The second issue discussed by Na, "states' and school districts' opt-out option" derives from the Lampkin case. Lampkin is noted as the "landmark case since it was the first ruling in which a federal court ordered a local government to comply with Title VIIB of the McKinney-Vento Act” (Na, 2008, p. 11). Na stresses compliance is only expected when the state or district accepts federal funds. By not accepting the funds, the LEA has no obligation to ensure the provisions of the Act. Thus, the McKinney Vento Homeless Act may have the best provisions for educating homeless youth, but without federal enforcement of the provisions no significant change will occur. 


\section{CHAPTER III \\ RESEARCH DESIGN \\ Statement of the Problem}

Since colonial days, the homeless population has changed by definition. Not until the middle of the 1980's was entire families noticed by the general public and government agencies. The introduction of the McKinney Vento Homeless Act in 1987 brought national attention to the growing homeless population. Studies have been conducted to look at aspects of homelessness, causes for homelessness, and barriers to enrolling homeless children. Qualitative research has been conducted to reveal counselor opinions of enrollment procedures and services available to homeless youth (Walsh \& Buckley, 1994). The importance of principal opinions on the services available and the procedures for obtaining those services during the enrollment procedure is essential to the educational success of homeless youth. This study looks at both the legislative intent of the law and the actual impact of the law now that it has been in effect for over 25 years. This study will be a post-adoption policy analysis using, when relevant, a theoretical lens to determine the efficacy of the legislation.

\section{Research Questions}

1. What were the legislative purposes and goals of the McKinney-Vento Act?

2. What has been the actual effect of the McKinney-Vento Act? 
3. Have the actual effects substantially obtained the original purpose and goals of the McKinney-Vento Act?

\section{Significance of Study}

Researchers have studied the McKinney Vento Act to determine the effects of homelessness on education of the student. However, no post-adoption policy analysis has been conducted to ascertain the efficacy of the Act. The review of the Act through a postadoption policy analysis will provide relevant information to be utilized in political settings to address positive and negative affects created by the policy.

Compulsory education laws stipulate the necessity of educating all students to enhance our society and raise the common knowledge for the better meant of society. Homeless students, like all other students have an equal right to basic education through the public school system.

In addition, laws have been enacted to reinforce that separate is not equal. Thus, homeless students must be educated alongside all other populations in their school of origin.

\section{Limitations}

The McKinney Vento Act is a federal act. However, this research will be limited to the effects the McKinney Vento Act has resulted in central Illinois. Specifically, this study will look at the effects the Act has implicated on the rural populations south of Interstate 80 and north of Interstate 70.

\section{Methodology}

The research methodology being used in this study is integrated policy analysis. A general definition of policy analysis presented by Dunn states: "Policy analysis is an 
applied social science discipline which uses multiple methods of inquiry and argument to produce and transform policy-relevant information that may be utilized in political settings to resolve policy problems." (Dunn, p. 35) Unlike a qualitative or quantitative methodology, the methodology of policy analysis draws from many different disciplines including public administration, law, and history, as well as many different methodologies. Moreover, unlike other inquiry methods, policy analysis is both a method to gather information and a vehicle to advocate for a given policy position.

"The policy analyst may therefore be expected to produce information and reasoned arguments about three kinds of questions: (1) values whose attainment is the main test of whether a problem as been resolved; (2) facts whose presence may limit or enhance the attainment of values; and (3) actions whose adoption may result in the attainment of values and the resolution of problems." (Dunne, p. 36)

In working toward this goal, the policy analyst has three approaches at his or her disposal. The first is empirical, which is primarily concerned with describing cause and effect. Second is evaluative, through which the worth or value of a policy is examined. Finally, there is the normative approach in which "advocacy" appears; this approach is concerned with recommending ways to resolve public policy problems. It becomes clear when looking at these three methods, that policy analysis has a "values" component; something that is frowned upon by other disciplines, which believe values and facts should be kept separate.

In policy analysis, "there are five policy-information components that are transformed into one another by using six policy analytic methods." (Dunn, p. 48) The five policy-information components are policy problems, policy performance, policy actions, policy outcomes, and policy alternatives. The six policy analytic methods are problem structuring to identify the policy problem being researched, forecasting future 
consequences of policies, recommendation of a future course of action, monitoring of causes and consequences of a policy, evaluation, and practical inference. All of these items are interdependent. This transformational and dynamic method of inquiry can be employed in a prospective policy analysis (prior to the adoption of the policy), a retrospective or post-adoption policy analysis (to evaluate the efficacy of the policy) or an integrated policy analysis. This study will employ the last method, an integrated policy analysis. The reason for this is that an integrated policy analysis provides for the collection and transformation of information both prior to and after the actual policy action. "This means that the analyst may engage in the clockwise transformation of policy-information components many times before a satisfactory resolution of a policy problem is found." (Dunn, p. 54) In other words, by using an integrated policy analysis approach, the researcher has the ability to not only collect information regarding what was occurring prior to the adoption of the policy, but will also continue to collect information regarding the effects of the policy after its adoption, integrating and synthesizing all the information to reach a conclusion and recommendations. Therefore, the researcher is able to draw on all of the disciplines associated with prospective policy analysis (public administration, law, ethics, etc.) but can continue on into evaluation of the effects of the policy, along with concurrent changes in values, goals, and objectives of both society and policy makers; a truly multidisciplinary approach.

The materials utilized for this research will include the legislation enacted to establish the policy. This will include the reauthorizations of policies that include aspects of homeless legislation. Specific legislation will include statue from as early as 1592 
addressing "those in economic distress" (Trattner, 1994), federal legislation, state statue, local school district policy, and pending proposals to reauthorize existing laws.

Throughout the evolution of homeless law, scholars and educators have commented on educating the homeless. This includes researchers collecting data on the effect of each policy on school district resources, state resources, and student achievement. Researchers have also reviewed the number of children being served under the legislation. Finally, relevant research questions the definition of homeless.

Homeless policy must draw on the social structure of the nation. Looking at the Marxist themes of socioeconomic conditions and class structure, how does this relate to homeless policy and the evolution of that policy in America? The Marxist theory shows the way socioeconomic status affects class structure and ultimately then homelessness. Legislation calls for all students to be educated to a minimum standard, lists education as an inherent right and indicates this will be free (my emphasis). This is not possible with the current financial condition of the Union and the oppression of the low socioeconomic population.

Studying homelessness through the critical research framework and incorporating the tenets of anti-oppressive education provides an opportunity to review the true aspects of the McKinney Vento Homeless Act. Does this policy support the intention of the Act? Will this policy provide opportunities for change within society? Does change come from policy or the reaction of the population to the policy? Although this analysis is for the McKinney Vento Homeless Act, this analysis is also looking at the how the policy is impacting social justice now and what stage is the Act setting for the future? 
In other words, by using an integrated policy analysis approach, the researcher has the ability to not only collect information regarding what was occurring prior to the adoption of the policy, but will also continue to collect information regarding the effects of the policy after its adoption, integrating and synthesizing all the information to reach a conclusion and recommendations. Therefore, the researcher is able to draw on all of the disciplines associated with prospective policy analysis (public administration, law, ethics, etc.) but can continue on into evaluation of the effects of the policy, along with concurrent changes in values, goals, and objectives of both society and policy makers; a truly multidisciplinary approach. 


\section{CHAPTER IV \\ LEGISLATION, ADMINISTRATIVE PROCEDURES, AND PROTECTED CLASS \\ Section 1: Legislation}

Although the McKinney-Vento legislation has developed over centuries of public policy, the actual legislation that exists today began in 1987. Court cases that helped shape the legislation will be discussed in Chapter V. It is important to note here the evolution of the Act and point out the changes that occurred at each reauthorization.

In 1987, President Ronald Reagan signed the McKinney Vento Act into law. This was "the first systematic attempt to address the needs of the homeless" (Na, 2008). The Subtitle VII - B of the McKinney-Vento Homeless Assistance Act established the Education for Homeless Children and Youth Program (EHCY). This program allocates federal money to states to "ensure that each child of a homeless individual and each homeless youth have equal access to the same free, appropriate public education..." (Petersburg, 2008). In addition, the Act ensured students were not segregated due to homelessness alone, and ensured homeless students had access to the same "challenging state student academic achievement standards to which all students are held" (Petersburg, 2008).

The McKinney-Vento Act (P.L 101-645) was amended in 1990. The purpose of this amendment was to strengthen the policy language to "ensure the success of homeless children in school" (Petersburg, 4). Other changes to the Act made available with the 
amendment included allowing direct services to utilize grant funds and increasing the 1991 federal funding to fifty million dollars (Petersburg, 4).

The Improving America's Schools Act of 1994 (P. L. 103-382) served to reauthorize and amend the McKinney Act. The new provisions provided local agencies greater funding flexibility, added preschool services, parent flexibility over choice of school, and insisted educational entities coordinate with housing authorities. These provisions assisted local liaisons in the placement of students by reducing barriers to enrollment, but funding still remained an issue. Students were still not receiving appropriate access to programs, programs were eliminated, and only a small portion of the homeless students were being served (Petersburg, 4).

In 1999, Representative Judy Biggert (IL-R) proposed changes to federal legislation. In her proposal, Representative Biggert included the provisions outlined in the Salazar $v$. Edwards provisions. This legislation becomes known as the McKinney-Vento Homeless Assistance Act of 2001. The name change was to honor the two original sponsors of the Act: Bruce Vento (D, Minnesota) and Stewart McKinney (R, Connecticut). Both died prior to the changes (NCHE, 3).

In 2001 the process began to reauthorize the McKinney -Vento Homeless Education Assistance Improvements Act in the No Child Left Behind Act (P.L. 107-110). President George W. Bush signed the legislation on January 8, 2002 required any district receiving funds to provide a homeless liaison. Many of the newly authorized requirements were in direct response to court case decisions between 1998 and the signing. Specifically, the new authorizations included students were to be enrolled immediately. Other important aspects of the 2002 reauthorization include: students being allowed to remain in the school of origin, 
parent choice of school, and requiring school districts share transportation costs between the school of origin and district where parent resides in the event of a dispute (Petersburg, 5).

The Homeless Emergency Assistance and Rapid Transition to Housing (HEARTH) Act of 2009 authorized and amended the McKinney-Vento homeless assistance programs administered by HUD (Duffield, 2010). The HEARTH Act provides funding to communities for emergency shelter, transitional housing, permanent supportive housing, and support services. This Act provided a slightly broader definition of homeless and provided definitions for a variety of other terms, including chronic homelessness (Duffield, 4). Specific requirements for homeless liaisons provided in this Act include: notifying homeless children and families of their rights under the McKinney Act, keeping students in their school of origin as much as possible, and ensuring homeless youth are connected to the appropriate services and programs available (Duffield, 8). The HEARTH Act provided independent youth the ability to complete the Free Application for Federal Student Aid (FAFSA) without parent input. Unaccompanied youth are now able to gain financial assistance to higher education (Duffield, 10).

Throughout the evolution of the McKinney-Vento Act and the reauthorizations through the variety of bills, the central themes are consistent. Barriers should be removed to allow immediate enrollment of homeless youth, educational opportunities should be consistent between homeless students and students with fixed housing, and the homeless liaison should be working with homeless children and families to ensure students are not segregated or stigmatized by their living conditions. 


\section{Section 2: Administrative Procedures}

The Salazar v. Edwards litigation provision established specific steps for Chicago schools to comply with federal legislation and state statue. These steps lead to the administrative procedures in effect today (Ableidinger, 2004).

Judge Michael Brennan Getty outlined six requirements for the Chicago Board of

Education. The requirements were listed in the settlement agreement summary:

(1) to undertake a massive information campaign on the rights of individuals experiencing homelessness;

(2) to train school personnel about the requirements of the act and how to comply with it;

(3) to designate school liaisons for identifying, assisting, and enrolling homeless children;

(4) to provide bus passes so homeless children could attend their schools of origin;

(5) to inform homeless parents about the dispute resolution process; and

(6) to comply with reporting and information production requirements. (Ableidinger, 5)

These requirements become engrained in the amended version of the McKinney-Vento Act of 2002. In the 2004 Fall School Law Bulletin, Ableidinger reports the essential provisions of the 2002 Act designates official duties at the federal, state, and local levels.

\section{McKinney-Vento 2002 Essential Provisions}

Federal legislation regarding the education of homeless children falls to the secretary of the U.S. Department of Education. The McKinney - Vento Act requires the U.S. Department of Education to provide “...oversight, support, and technical assistance to states, and evaluating and disseminating information about programs designed to meet the educational needs of homeless students" (Ableidinger, 6).

Ableidinger further states that at the state level, the state education agency (SEA) is required to ensure all homeless children are provided with a free, appropriate public education, "including a public preschool education, as provided to other children and 
youth" (Ableidinger, pg. 6). The required state coordinator for the education of homeless youth coordinates the provision of services and technical assistance to local educational agencies (LEAs). Part of the compliance of the state coordinator is to ensure LEA liaisons are collecting information and data in the state, carrying out the state developed plan to remove barriers to homeless students, and ensure homeless children are not "segregated, stigmatized, or isolated" due to their homelessness (Ableidinger, 7).

Each state plan must meet the following four requirements:

1) "descriptions of how homeless children will be given the chance to meet state academic standards;

2) how states will identify homeless children and measure their needs;

3) "programs... to heighten awareness of... specific needs of ... homeless youths; and

4) removal of "barriers to the enrollment and retention of homeless children" (Petersburg, 2008, pg. 4).

These requirements shift the responsibilities to educate homeless children and youth to the state. The state plan then pushes the requirements to the local level. Each of those responsibilities will be discussed in depth. The McKinney-Vento provisions are the responsibility of the local school liaison and school administrator(s). These provisions fall into ten areas of implementation: segregation, school selection, enrollment, dispute resolution, records, transportation, and access to comparable services, academic achievement standards, local liaisons, and coordination (Ableidinger, 7).

\section{Segregation \& School Selection}

\section{Section 722. e (3) PROHIBITION ON SEGREGATING HOMELESS STUDENTS-}

(A) IN GENERAL- Except as provided in subparagraph (B) and section 723(a)(2)(B)(ii), in providing a free public education to a homeless child or youth, no State receiving funds under this subtitle shall segregate such child or youth in a separate school, or in a separate program within a school, based on such child's or youth's status as homeless. 
(B) EXCEPTION- Notwithstanding subparagraph (A), paragraphs (1)(J)(i) and (3) of subsection (g), section 723(a)(2), and any other provision of this subtitle relating to the placement of homeless children or youths in schools, a State that has a separate school for homeless children or youths that was operated in fiscal year 2000 in a covered county shall be eligible to receive funds under this subtitle for programs carried out in such school if -

(i) the school meets the requirements of subparagraph (C);

(ii) any local educational agency serving a school that the homeless children and youths enrolled in the separate school are eligible to attend meets the requirements of subparagraph (E); and

(iii) the State is otherwise eligible to receive funds under this subtitle.

(C) SCHOOL REQUIREMENTS- For the State to be eligible under subparagraph (B) to receive funds under this subtitle, the school described in such subparagraph shall -

(i) provide written notice, at the time any child or youth seeks enrollment in such school, and at least twice annually while the child or youth is enrolled in such school, to the parent or guardian of the child or youth (or, in the case of an unaccompanied youth, the youth) that -

(I) shall be signed by the parent or guardian (or, in the case of an unaccompanied youth, the youth);

(II) sets forth the general rights provided under this subtitle;

(III) specifically states -

(aa) the choice of schools homeless children and youths are eligible to attend, as provided in subsection $(\mathrm{g})(3)(\mathrm{A})$;

(bb) that no homeless child or youth is required to attend a separate school for homeless children or youths;

(cc) that homeless children and youths shall be provided comparable services described in subsection $(g)(4)$, including transportation services, educational services, and meals through school meals programs; and 
(dd) that homeless children and youths should not be stigmatized by school personnel; and

(IV) provides contact information for the local liaison for homeless children and youths and the State Coordinator for Education of Homeless Children and Youths;

(ii)(I) provide assistance to the parent or guardian of each homeless child or youth (or, in the case of an unaccompanied youth, the youth) to exercise the right to attend the parent's or guardian's (or youth's) choice of schools, as provided in subsection (g)(3)(A); and

(II) coordinate with the local educational agency with jurisdiction for the school selected by the parent or guardian (or youth), to provide transportation and other necessary services;

(iii) ensure that the parent or guardian (or, in the case of an unaccompanied youth, the youth) shall receive the information required by this subparagraph in a manner and form understandable to such parent or guardian (or youth), including, if necessary and to the extent feasible, in the native language of such parent or guardian (or youth); and

(iv) demonstrate in the school's application for funds under this subtitle that such school

(I) is complying with clauses (i) and (ii); and

(II) is meeting (as of the date of submission of the application) the same Federal and State standards, regulations, and mandates as other public schools in the State (such as complying with sections 1111 and 1116 of the Elementary and Secondary Education Act of 1965 and providing a full range of education and related services, including services applicable to students with disabilities). (Elementary \& Secondary Education Part C Homeless Education, 2001)

Oliver L. Brown et.al. v. the Board of Education of Topeka (KS) et.al provided the forum for determining separation is inherently unequal (Berkowitz, 7). The federal statue prohibits separating homeless students. Homeless students must be housed for educational purposes with their peers. This includes separating students within a school. Homeless youth may qualify for separation on the guidelines utilized for all students 
segregated for special circumstances but not due to homelessness. The local entity must implement procedures and policies to prevent segregation or stigmatization of any student due to homelessness (Ableidinger, 9).

\section{School Selection}

As indicated above in Subtitle B - Education for Homeless Children and Youths Section 722.3 c. I. II, the parent of a homeless youth is allowed to choose between the school where the child attended immediately prior to becoming homeless and the school where the family relocates due to the homeless situation. The LEA is required to keep the student in the first district, known as the "school of origin", unless the parent prefers the child attend where the family resides. Research by Wong, et al in 2004 linked educational stability to academic success. This finding by Wong and his associates provided clarification to the legislation supporting students continued enrollment in the school of origin. Homeless youth experience feelings of isolation, anxiety, depression, and withdrawal (Wong, et al, pg. 3). Enrollment in the school of origin provides homeless youth with educational stability; providing familiarity, support, and services in the only stable environment the child experiences.

\section{Records}

Section 722.g 1 (H) Strategies to address other problems with respect to the education of homeless children and youths, including problems resulting from enrollment delays that are caused by -

(i) immunization and medical records requirements;

(ii) residency requirements;

(iii) lack of birth certificates, school records, or other documentation;

(iv) guardianship issues; or

(v) uniform or dress code requirements. (Elementary \& Secondary Education Part C - Homeless Education, 2001)

The receiving school is responsible for helping homeless youth obtain their academic and medical records required to enroll in school. The McKinney-Vento Act 
places this responsibility with the LEA liaison. The liaison must arrange for the "retention and maintenance of records of homeless students and make pertinent information readily available when students switch schools" (Ableidinger, 7).

It is important to note that student records in Illinois are also governed by the Illinois School Student Records Act (ISSRA) and the Federal Family Educational Rights and Privacy Act (FERPA). Administrators must adhere to the procedures and guidelines established by these two laws (Schwartz \& Day, 2012, pg. 47).

\section{Enrollment}

Section 722.e 3 g 3 (C) ENROLLMENT- (i) The school selected in accordance with this paragraph shall immediately enroll the homeless child or youth, even if the child or youth is unable to produce records normally required for enrollment, such as previous academic records, medical records, proof of residency, or other documentation.

(ii) The enrolling school shall immediately contact the school last attended by the child or youth to obtain relevant academic and other records. (Elementary \& Secondary Education Part C - Homeless Education, 2001)

School staff is required to immediately enroll homeless youth, with or without records normally required to enroll a student. Parents of children lacking medical records, including immunizations must be referred to the LEA liaison. The liaison is responsible for assisting the parent/guardian in obtaining the records while the student attends school (Ableidinger, 7).

In addition, enrollment as defined by McKinney legislation refers to all aspects of the educational experience, including full participation in school activities. Any barriers to the student attending or participating in activities must be removed. A homeless student cannot be denied participation for lack of records, residency issues, dress code requirements, or guardianship problems (Ableidinger, 7). 


\section{Dispute Resolution}

722 e 3 g 3 (E) ENROLLMENT DISPUTES- If a dispute arises over school selection or enrollment in a school -

(i) the child or youth shall be immediately admitted to the school in which enrollment is sought, pending resolution of the dispute;

(ii) the parent or guardian of the child or youth shall be provided with a written explanation of the school's decision regarding school selection or enrollment, including the rights of the parent, guardian, or youth to appeal the decision;

(iii) the child, youth, parent, or guardian shall be referred to the local educational agency liaison designated under paragraph (1)(J)(ii), who shall carry out the dispute resolution process as described in paragraph $(1)(\mathrm{C})$ as expeditiously as possible after receiving notice of the dispute; and

(iv) in the case of an unaccompanied youth, the homeless liaison shall ensure that the youth is immediately enrolled in school pending resolution of the dispute. (Elementary \& Secondary Education Part C - Homeless Education, 2001)

Every state has established dispute resolution measures to resolve conflicts between homeless student (parents) and district providing services. The LEA is responsible for providing written explanation of all decisions of disputes when disagreements exist. The LEA is responsible for notifying all parties of their right to appeal and must enroll the student in the school preferred by the youth and guardian while the dispute is pending. Resolutions must be sought as quickly as possible by the LEA. The LEA liaison is also responsible for aiding unaccompanied youth in maneuvering the process of dispute resolution (Ableidinger, 7).

The Illinois State Board of Education has outlined dispute procedures. Included in these procedures are the requirements of the LEA to provide the parent, guardian, or unaccompanied youth with a letter explaining the district position. The letter must include referrals to free/reduced legal assistance, and an outline of the dispute resolution 
procedures. A copy of the letter must be forwarded to the regional superintendent of schools and Illinois' Coordinator for the Education of Homeless Children and Youth. The regional superintendent will appoint an "ombudsperson". This ombudsperson will oversee the dispute resolution process, including conducting a meeting to allow the presentation of all relevant facts by all participants. At the conclusion of the meeting, the ombudsperson will relay in writing the decision and inform the participants of the ability to be reviewed by the State Coordinator (ISBE, 2009).

\section{Transportation}

Section 722 e 3 C (II) coordinate with the local educational agency with jurisdiction for the school selected by the parent or guardian (or youth), to provide transportation and other necessary services; (Elementary \& Secondary Education Part C - Homeless Education, 2001)

Historically, the U.S. Department of Education has listed transportation as the number one barrier to homeless children and youth enrollment. For that reason, every state plan is required to list assurances students will be provided transportation from a temporary residence, due to homelessness, to the school of origin. The two LEA liaisons involved (liaison for school of origin and liaison for school of temporary residence) must agree on the method of transportation and apportioning the expenses of the transportation. In the event an agreement is not reached on the shared expenses, the parties must equally share the cost throughout the resolution process (Ableidinger, 8).

\section{Access to Comparable Services}

722 e $3 \mathrm{~g}$ (4) COMPARABLE SERVICES- Each homeless child or youth to be assisted under this subtitle shall be provided services comparable to services offered to other students in the school selected under paragraph (3), including the following: (Elementary \& Secondary Education Part C — Homeless Education, 2001) 
School districts must provide services to homeless students comparable to those services offered to all student populations, including special populations. These services may include but are not limited to special education, school nutrition, pre-school, vocational education, gifted and talented programs, and transportation. If the homeless student meets the same qualifications as any other participate, the homeless student must be provided those services. The McKinney Act requires equal access to homeless youth to all school services as provided for all subsets of the school population (Ableidinger, 8).

\section{Academic Achievement Standards}

$722 \mathrm{~g}$ (1) IN GENERAL- Each State shall submit to the Secretary a plan to provide for the education of homeless children and youths within the State. Such plan shall include the following:

(A) A description of how such children and youths are (or will be) given the opportunity to meet the same challenging State academic achievement standards all students are expected to meet. (Elementary \& Secondary Education Part C - Homeless Education, 2001)

Homeless students must meet the same academic achievement standards as nonhomeless students. Homeless students are required to participate in state wide and local assessments. The state education plan must outline how the homeless student is being prepared for standards required of all students (Ableidinger, 8).

\section{Local Liaisons}

722 e 3 g (6) LOCAL EDUCATIONAL AGENCY LIAISON-

(A) DUTIES- Each local educational agency liaison for homeless children and youths, designated under paragraph (1)(J)(ii), shall ensure that -

(i) homeless children and youths are identified by school personnel and through coordination activities with other entities and agencies; 
(ii) homeless children and youths enroll in, and have a full and equal opportunity to succeed in, schools of that local educational agency;

(iii) homeless families, children, and youths receive educational services for which such families, children, and youths are eligible, including Head Start and Even Start programs and preschool programs administered by the local educational agency, and referrals to health care services, dental services, mental health services, and other appropriate services;

(iv) the parents or guardians of homeless children and youths are informed of the educational and related opportunities available to their children and are provided with meaningful opportunities to participate in the education of their children;

(v) public notice of the educational rights of homeless children and youths is disseminated where such children and youths receive services under this Act, such as schools, family shelters, and soup kitchens;

(vi) enrollment disputes are mediated in accordance with paragraph (3)(E); and

(vii) the parent or guardian of a homeless child or youth, and any unaccompanied youth, is fully informed of all transportation services, including transportation to the school of origin, as described in paragraph (1)(J)(iii), and is assisted in accessing transportation to the school that is selected under paragraph (3)(A). (Elementary \& Secondary Education Part C - Homeless Education, 2001)

In 2008, Benjamin Petersburg conducted research into improving local liaisons' ability to provide services to homeless youth. In his research, he cited the current duties of the liaison under the McKinney-Vento Act. The six duties Petersburg identifies are:

1) identifying and enabling homeless children to enroll in school immediately and making sure that they have an equal opportunity to succeed;

2) making sure these homeless children have access to other federal programs offered by the particular local educational agency and referring them to health care services;

3) making sure homeless parents are informed and able to participate in educational opportunities for their children; 
4) making sure information concerning homeless students' educational rights is given out publicly where these children obtain services;

5) making sure enrollment disputes are handled properly;

6) making sure the parents or guardians of homeless students are informed of transportation rights (2008, pg. 7).

The liaison provides guidance, resources, and assists all homeless youth and their parents during the dispute process. Liaisons must assist in gathering academic and medical records, including immunization records. The liaison is also responsible for training school staff to assist in the identification of homeless youth (Ableidinger, 8).

\section{Coordination}

722 (f) FUNCTIONS OF THE OFFICE OF COORDINATOR - The Coordinator for Education of Homeless Children and Youths established in each State shall -

(1) gather reliable, valid, and comprehensive information on the nature and extent of the problems homeless children and youths have in gaining access to public preschool programs and to public elementary schools and secondary schools, the difficulties in identifying the special needs of such children and youths, any progress made by the State educational agency and local educational agencies in the State in addressing such problems and difficulties, and the success of the programs under this subtitle in allowing homeless children and youths to enroll in, attend, and succeed in, school;

(2) develop and carry out the State plan described in subsection (g);

(3) collect and transmit to the Secretary, at such time and in such manner as the Secretary may require, a report containing such information as the Secretary determines is necessary to assess the educational needs of homeless children and youths within the State;

(4) facilitate coordination between the State educational agency, the State social services agency, and other agencies (including agencies providing mental health services) to provide services to homeless children, including preschool-aged homeless children, and youths, and to families of such children and youths;

(5) in order to improve the provision of comprehensive education and related services to homeless children and youths and their families, coordinate and collaborate with -

(A) educators, including child development and preschool program personnel;

(B) providers of services to homeless and runaway children and youths and homeless families (including domestic violence agencies, shelter operators, transitional housing facilities, runaway 
and homeless youth centers, and transitional living programs for homeless youths);

(C) local educational agency liaisons designated under subsection

(g)(1)(J)(ii) for homeless children and youths; and

(D) community organizations and groups representing homeless

children and youths and their families; and

(6) provide technical assistance to local educational agencies in coordination with local educational agency liaisons designated under subsection $(\mathrm{g})(1)(\mathrm{J})(\mathrm{ii})$, to ensure that local educational agencies comply with the requirements of section 722(e)(3) and paragraphs (3) through (7) of subsection (g). (Elementary \& Secondary Education Part C — Homeless Education, 2001)

McKinney-Vento requires state and local liaisons to work in cooperation with social services, housing agencies, domestic violence agencies, shelter operators, transitional housing facilities, runaway and homeless youth centers, transitional living programs for homeless youth, and all other public or private social services (Ableidinger, $9 \&$ ISBE). In addition, all districts should facilitate access of homeless families to food stamps, Medicaid, employment services, etc. (ISBE, 2009). The liaison should promote a policy of cooperation for the benefit of the child and to alleviate the challenges linked with homelessness (Ableidinger, 9).

\section{Section 3: Protected Class}

Throughout the development of the legislation, the question of homelessness as a protected class surfaces. In 2012, Rhode Island enacted a Homeless Person's Bill of Rights. In August 2013, Illinois became the second state to enact a Homeless Bill of Rights. Connecticut also enacted a Homeless Person's Bill of Rights in 2013. The difference in the three pieces of legislation is Rhode Island and Illinois allow the person to sue and claim damages under the law. In Connecticut, a person is only protected under other legislation (Brody \& Goldberg, 2013). 
Brody \& Goldberg (2013) contend that since there is no federal law prohibiting discrimination due to homelessness, the disparate impact theory could be applied to federal legislation. Brody and Goldberg further explain, "under the "disparate impact" theory of discrimination, a practice is unlawful if it disproportionately harms members of protected classes..." (1). Since the homeless population is disproportionately AfricanAmerican or Hispanic, and/or suffer from mental illness, the federal employment laws protect them from discrimination due to race, nationality, or disability, thus recognizing a disparate impact theory (Brody \& Goldberg, 1).

Illinois homeless residents have been afforded the right to employment. The law took effect immediately, providing people with equal rights under the law. People cannot be discriminated against because they lack a permanent address. Other provisions include the right to emergency medical care, right to vote, and the right to move freely in public buildings and spaces (Fortino, 2013). 


\section{CHAPTER V}

\section{COURT CASES IMPACTING REAUTHORIZATION}

Illinois case law initiates the foundation for all reauthorizations in 1992.

Homeless parents and children in Chicago filed a class action lawsuit in the Illinois State Court. The parents were represented by the Children's Rights Project of the Legal Assistance Foundation, the Homeless Advocacy Project of the Legal Assistance Foundation, and the Northwest Office of the Legal Assistance Foundation of Chicago. The suit was filed against the Illinois State Board of Education, the Illinois Coordinator for Homeless Children and Youth, the State Superintendent of Education, the Chicago School Board, and the Chicago School Reform Board of Trustees. In this landmark case, Salazar v. Edwards (No. 92 CH 5703[State Court]), the parents of homeless youth alleged the named defendants "practices and policies relating to the education of homeless children in Chicago violated due process, the Illinois State Constitution, and various Illinois statues" (Malone, 2006).

The suit maintained homeless children were consistently negated their right to remain in the school of origin, were imposed with arduous transfer requirements, delayed and/or denied timely transportation, parent requests were ignored, and children were denied access for days or even weeks without educational opportunities (Malone, 1).

Four years after the initial filing, on November 21, 1996, a settlement was reached that established "the policies and procedures for enrolling, transferring, and maintaining school attendance for homeless children" (Malone, 2). Three years later, Judge Michael 
Brennan Getty would revisit the case. The Court found the City (Chicago Public Schools) in violation of the Consent decree. Judge Getty appointed an independent monitor to oversee the implement of the earlier judgment. The monitor was required to notify families of their rights, the availability of dispute resolution procedure, designate a liaison in every school, distribute transportation passes (bus), and reduce the barriers for the homeless youth to gain educational opportunities (Malone, 2). These procedures become the foundation for the 2001 reauthorization.

In 1994, a Chicago suburban school district attempted to deny enrollment to three homeless youth. The media support surrounding this case and the Salazar case encouraged Illinois legislators to amend the Illinois School Code to include homeless children education. Advocates of homeless education pushed for Illinois House Bill 3244. In 1995, the Illinois Education for Homeless Children Act (EHCA) was enacted. The provisions of the bill included:

(1) requires school districts to immediately enroll homeless students without requiring the production of records, immunizations, physical examinations or transfer forms; (2) gives parents the power to determine which choice of schools is in the "best interest" of their child including choosing to remain the child's "school of origin;" (3) provides an unequivocal right to transportation if the child returns to the home school with a directive that school districts agree on sharing costs or splitting them equally for a child living in one district but returning to the school of origin in another; (4) defines "homeless" consistently with the McKinney Act and even somewhat more liberally; (5) creates a right to a "dispute resolution" process (allowing the child to enroll, attend and receive transportation during any dispute); and (6) creates the right to advocacy assistance for the family or child and the right to file a civil action for enforcement. (Heybach, 3)

In conjunction with the Salazar Settlement, the Illinois State Board of Education (ISBE) issued the first educational rights of homeless students' policy. The policy had 
strengths but overall was not effective. Although ISBE was unable to make significant advances in the education of homeless youth, the Salazar litigation initiated changes for the largest group of homeless students in Illinois. All across the country, people were watching the third largest school district undergo changes in how to educate the growing populations of homeless youth (Heybach, 4).

In 2005, ISBE issued a stronger policy on homeless education. This new policy had provisions for handling dispute resolutions, including the right to appeal to the State Coordinator and final determination made by the ISBE State Superintendent. Second, students accessing a different shelter on a nightly basis can select any attendance area school to attend. And finally, school personnel have a duty to assist students in promptly enrolling in the appropriate school (Heybach, 4).

Additional changes in ISBE policy take place in 2007. The revision adopted the "Equal Opportunity for All Students" regulations (prohibits exclusion, discrimination, or segregation) and strengthened funding for preschool attendance for homeless children.

During this time, the District of Columbia began another lengthy court case that had lasting implications on federal funding for schools. In Lampkin v. District of Columbia, 27 F. 3d 605 (D.C. Cir. 1994), cert. denied, 513 U.S. 1016 (1994), on remand, 879 F. Supp. 116 (D.D.C. 1995), dissolving injunction, 886 F. supp. 56 (D.D.C. 1995), ten homeless parents alleged the District failed to meet implement the provisions of the McKinney-Vento Act. The District allegedly:

(1) failed to implement a best interest standard in placing homeless children in schools; (2) failed to ensure transportation to and from the school that is in the best interest of homeless children to attend; (3) failed to coordinate social services and public education for homeless children, and to ensure access to comparable educational services and 
school meal programs; and (4) failed to provide access to free, appropriate education for homeless children. (Petersburg, 5)

The court found in favor of the plaintiffs and required the District to (1) identify homeless youth immediately upon arrival to an intake center, and within 72 hours provide transportation and educational services. Second, bus tokens were to be provided to all homeless children and parents/adult escort who accompany a homeless child required to travel over 1.5 miles to a primary or secondary school; and remove any delay incurred to a once-a-week token distribution at shelters occupied by homeless students and their parents.

Shortly after the court handed down the decision, the District withdrew from the EHCY Program. By withdrawing and refusing the funding of the program, the District had no obligation to comply with the court decision. The court contended since this issue was a social issue, the resolution needed to come from the voters.

The District waited until January 2006 to reapply for McKinney-Vento Homeless Assistance Act funds. The District was the only district in the country to not access the federal assistance (Slater, 2006).

In May 2002 a suit was filed in Maryland, Bullock, et al. v. Board of Education of Montgomery County, et al. alleged that the Montgomery County Board of Education, an LEA, and Jerry Weast, superintendent violated the McKinney-Vento Act. This case establishes several key legal aspects for later challenges of the McKinney-Vento Act. Specifically, this case established homeless students and their parents met the Federal Rule of Civil Procedure 23 and could be joined in class certification. This case sets president for future homeless class action cases, providing the necessary background needed to establish Rule 23. In summary, the plaintiffs successfully met the four 
requirements of numerosity, commonality, typicality, and adequacy of representation (Bullock v Montgomery County, 2002).

In 2007, Kaleuati v. Tonda [Civ. No. 07-504] was filed in Hawaii. This class action lawsuit centered on how Hawaii implemented the McKinney-Vento legislation. In this case, the plaintiffs alleged the state failed "to provide equal access to free and appropriate education to ... homeless children” (Petersburg, 6).

Hawaii has one school district for the state. In 2007, there was one liaison for the district/state. The complaint contended the Hawaii Department of Education (HDOE) was unable to monitor the implementation of the McKinney Act. The court determined the school district must revise the Geographical Exception requirement for homeless students, devise a schedule for disseminating educational rights to homeless students to schools and other agencies, and submit a plan for independent monitoring of the McKinney program (Petersburg, 7).

This case settled in August 2008. The State agreed to "make reasonable, goodfaith efforts to identify homeless children, to provide accurate information to families about homeless rights, and increased the number of liaisons to assist with the provisions (Petersburg, 7).

In January 2012, a lawsuit was filed in Alabama named Allen and Shaw v. Hoover City Schools. This case is still pending in the Alabama courts. The defendants include the Hoover City Board of Education that was in place in 2009, Superintendent Andy Craig, then-Assistant Superintendent Carol Barber, and Homeless Liaison Wayne Smith. The case alleges these defendants "failed to appropriately identify and provide appropriate 
services and supports to each plaintiff' (Powell Crain, 2). This case is gaining national attention due to Alabama limiting the reach of federal protections.

In the Allen and Shaw v. Hoover City Schools, the plaintiffs were both members of the Hoover High School football team. Both plaintiffs allege their coaches knew they were homeless, yet did not inform either student of their rights under the McKinney Act. Both students graduated in 2009. During their enrollment, both were required to supply receipts from the hotel where they resided. The hotel was located within another district boundary. Neither student was offered transportation options, nor were they provided access to the liaison for the school. Other violations to the provisions of the Act are also mentioned in depositions (Powell Crain 4). This case and others like it will continue to provide foundation for changes in the revisions to the McKinney-Vento Act. 


\section{CHAPTER VI}

\section{ADMINISTRATOR KNOWLEDGE AND APPLICATION Introduction to a Qualitative Study on Administrator Knowledge}

The purpose of the qualitative study conducted in 2011 was to determine administrator procedures and opinions on enrolling homeless youth. Another purpose was to determine the services being provided to homeless youth and their families by rural school districts in central Illinois.

This study sought the effects on student learning for homeless students in rural school districts as described by administrators. This study utilized qualitative methods of document analysis and semi-structured interviews. The following chapter will provide the results and analysis of the documents and interviews of the participants. The four participants were Ms. Token, Mr. Enright, Mr. Lone, and Mr. Danik. Each school district and all participants were given a pseudonym to provide confidentiality.

\section{Results: Participant Profile}

All four participants hold Illinois Type 75 Certification. Each participant is a principal in a rural school district in central Illinois. Pseudonyms have been utilized for both participants and their school districts to ensure anonymity. Documents were obtained from the Iroquois/Kankakee County ROE.

"Ms. Token" 
"Ms. Token" is a middle school principal at TMS. She has been in education for over fifteen years. Her career began as a classroom teacher. She held an assistant principal position for several years prior to becoming the principal. The district she works in has a free and reduced lunch population of approximately thirty-eight percent.

"Mr. Enright"

"Mr. Enright" is a principal/superintendent at a PK-8 school district in central Illinois. His career began as a classroom teacher/technology coordinator. He was principal in a different district prior to his current position. Although his current district has no students classified as homeless at this time, his prior district had a homeless population of approximately two percent. His current district has a free and reduced lunch population of thirty-three percent and his previous district had approximately forty percent.

"Mr. Lone"

"Mr. Lone" is a high school principal at GTHS. His career began as a classroom teacher. He quickly moved to the principal position after holding an assistant position for two years. His current district has a less than two percent homeless population and twenty-one percent free and reduced lunch population.

"Mr. Danik"

"Mr. Danik" is a middle school principal at OTMS. His career began as a classroom teacher. He was an assistant principal in a large urban middle school and then 
moved to the principal of this rural middle school. His current district has a free and reduced lunch population of approximately thirty percent. OTMS does not currently have any homeless students registered in their district.

\section{Document Analysis}

The document package distributed by the ISBE to the Iroquois/Kankakee County ROE was obtained by calling Dyanne Judd. The packet contained information for the immediate enrollment of homeless students in any school district in Illinois as provided by the ISBE and the McKinney Vento Homeless Act. The documents were reviewed by the researcher to determine their authenticity and validity as compared to the legislation. All documents were consistent with the Act.

The participants in this study were chosen through the selective sampling procedures. The researcher utilized the IIRC to determine rural school districts with twenty to forty percent free and reduced lunch population. All four participants are principals in rural central Illinois schools. As principals, all four participants are required to enroll students and ensure them a quality education. The ISBE documents hold principals accountable for ensuring identification, enrollment and services are provided to homeless youth.

\section{Research Issue}

The study was conducted to determine administrator knowledge on the procedures to enrolling homeless students in rural central Illinois schools. The study also looked at the services offered to homeless students and their families by rural Illinois schools. Each participant was asked to describe their experiences and the implications of enrolling homeless youth in their districts. The interviews provide a sampling of the procedures 
utilized by rural administrators and the effects on student achievement in those districts. The semi-structured interview process allowed for participants to elaborate on services offered to students. The interview probes were not presented in a specific order.

\section{Research Question 1: What services are being offered to homeless students enrolled in public schools?}

The interviews revealed numerous services offered by school districts in Central Illinois. These services were categorized into five themes. Those themes are housing, school supplies (including clothing), counseling, nutrition, and medical. In addition to these themes, the administrators commented on the lack of services in each category. The most obvious need of a homeless person may be the most difficult to obtain. The family would not meet the definition if they obtain a regular, fixed night time residence.

\section{Housing}

Rural districts lack the resources of urban districts when reviewing available social service agencies. Large urban communities provide homeless youth and their families with shelters for temporary living accommodations. Many rural communities lack a place for homeless families to live during economic hardships. Ms. Token expressed her relief in their community having two options for homeless families. The first was the government housing available in one community. The other was a motel that has been renovated as small apartments. Ms. Token did not know the exact circumstances available to families to obtain residence in either facility, but she did acknowledge that most homeless families in her district had either lived in the government housing prior to being homeless or were awaiting placement in the facility. She indicated that several 
families identified as homeless were living out of vehicles while the vehicle was parked at the renovated motel.

Mr. Enright indicated that several of the students enrolled as homeless in his district utilized a trailer parked on property located within his district. This accommodation was particularly difficult when the property was split between his district and the neighboring district. Although the address was within his district boundaries, the trailer was located across the district line. The student stated he was living with the grandmother in the house located in Mr. Enright's district, but the father was living in the trailer in the neighboring district. This geographic phenomenon further tested the district knowledge on the definition of homeless.

Mr. Lone refused enrollment to a student living with a relative based on the Illinois residency requirements. He indicated that the residence of the student was in another school district because the parent was living in the other district. He contended that since the relative in his district did not have legal custody of the youth, the district was not required to enroll that student as homeless.

In the fourth interview, Mr. Danik revealed no one was enrolled as homeless at this time. He did state that, "The question actually was are they homeless or are they between residences?" His experiences revolved around parents that had secured a residence in the district, but for a variety of reasons were unable to move into the facility. In the meantime, is the student homeless or are they living in temporary housing or is living in temporary housing homeless by the definition? 
All four principals struggled with the definition of temporary housing, residency, and homeless. Ms. Token explained her struggle with accessing housing for homeless families:

They are looking for information. And we try to provide what we can to them to let them know what the resources are, but I don't know that we have enough of that in our hands to know exactly how to move them on.

Although each principal had difficulty determining a solid definition for their homeless population, each was quick to reveal the needs of homeless children in their respectful district. For obvious reasons, all students need school supplies. Although the thought of a pen or pencil seems trivial, not all families are able to supply the necessary materials for the child.

\section{School Supplies}

Students at all ages require supplies to enhance their educational experience.

Although the basic supplies may vary from district to district, the need for those supplies and the inability of homeless youth to secure those supplies is a common theme among all four participants. Each participant list school supplies as a service provided to all homeless youth. Parents living in the low income bracket must use their resources on food, shelter and clothing. They rarely deem pencils, paper, and other school supplies as necessities.

Ms. Token described the need for school personnel to store supplies of homeless youth when they move to a different district. In her experience, if a family is identified as homeless and leaves the district, often times they will return. She has had several students leave and return several times during the same school year. By storing the items provided by the district for the student, she has avoided purchasing duplicate supplies for the same 
child in the same school year. On a similar note, Mr. Enright stated, "Usually through the ROE, we could offer school supplies." He explained that his staff assembles bundles for the students that cannot afford the supplies and qualify for free or reduced lunches, as well as for homeless students.

The Needy Kids Program offered by Ms. Token's school provides gentle used clothing to homeless students. Ms. Token's district was the only one that offered such a program. However, along with Ms. Token, Mr. Danik, Mr. Enright, and Mr. Lone described outside agencies that could provide that type of service to homeless students. Each would refer the family to a social worker through their counselor or Special Education Cooperative. The social worker would be responsible for referring the family to an outside agency to secure clothing items. Both Mr. Danik and Mr. Enright also cited the local churches as a resource for securing school supplies and clothing. The social worker becomes a key participant in the process of determining the needs of the homeless youth and family. While the social worker is supplying resources, their communication skills are utilized to set a positive tone for opening counseling opportunities.

\section{Counseling}

Administrators and teachers have many reasons for referring students for counseling services. The four principals interviewed all discussed the need for students declared as homeless to receive counseling services. Three of the four interviewed had counselors available in their buildings. These counselors were either employees of the district they service or where contracted by the district through an outside agency. Mr. Danik provides counseling services through Chestnut Health Systems (CHS); an organization that provides counseling in schools as well as at their headquarters in a 
nearby metropolitan area. CHS provides services every day to the district. Ms. Token contracts counseling services through the Institute of Human Resources (IHR). IHR provides in district counseling one day per week. Ms. Token stated:

I refer them to the counselor, when I know that this is the situation [homeless], because I can't imagine they don't have something to talk about. And they may not. And that's okay! They might not trust her either and don't want to share at first. But so far, they have all ended up in the counseling and it seems to serve them well.

Mr. Lone insisted counseling was one of the first services offered to his homeless students. His district provides the service through their district social worker. Mr. Lone commented, "Our social worker is one of the first people we involve in the process once we know the family is homeless." He discussed how the social worker will engage students in describing their unique situation. The social worker can then work with the family to provide additional services. He indicated intensive counseling was also offered through his county health department.

Another aspect of the counseling discussed by all the participants was the need to match the homeless student with a teacher. This teacher would be the mentor for the student and relay any problems experiences by the student to the appropriate personnel. The development of this relationship can provide needed emotional support to the student on a daily basis. The teacher will get to know the student and communication between the student and teacher can bridge the home/school gap. Classroom teachers often notice changes in student behavior that can be attributed to the homeless status before disclosure is made by the family. Ms. Token indicated students may wear the same clothing day after day. She also talked about the student complaining about lack of regular meals. Upon investigation, this may be the first indication of a family moving to homeless 
status. One of the first provisions for homeless youth is the immediate qualification for the school breakfast and lunch program.

\section{Nutrition}

The McKinney Vento Act calls for the immediate qualification of all homeless youth for the free breakfast and lunch program. Although parents/guardians are required to complete the form for the program, they are not required to meet income guidelines like other low income families. There is a place to indicate the family is homeless. Once the family is identified, other aspects of the document are not necessary.

All four principals indicated all students identified as homeless receive immediate enrollment in this free breakfast and lunch program. Ms. Token described a situation where the child was not enrolled as a homeless student, but through a series of unfortunate events, the family was displaced and homeless. Once the staff and Ms. Token became aware of the situation she stated:

But we have things we can make available to them if we know that they are in a hardship situation. And for us, the first step is we look to see if the student is on free and reduced lunch, and then we go from there.

The participants all agreed that the student would be unable to concentrate and learn without proper nutrition. The provisions of the McKinney Vento Act directly align to the needs of nutrition for homeless students. The development of the child along with the nutritional component to student learning will be addressed later. However, the nutrition of the child aligns directly with the medical needs of the child.

\section{Medical}

Students in homeless situations often are not provided with adequate dental and medical attention. They can enroll in school without the appropriate immunization 
records. The school is responsible for locating those records and/or providing information to the family to secure the documentation of the medical records. Three of the four administrators interviewed indicated they employ a school nurse to work with all students to ensure they are incompliance with state laws requiring immunizations, dental exams, eye exams and documentation to support those requirements. Mr. Enright was the only participant that did not have a school nurse to assist him in this task. He indicated his secretary was responsible for the collaboration of all pertinent records for enrollment. Although she is not a nurse, he was confident in her ability to obtain the appropriate documentation.

When Ms. Token was given the documents from the IKAN ROE, she recalled all the tasks her school nurse provided for homeless youth. Ms. Token praised the school nurse in her building for coordinating medical services to outside agencies for students with medical needs. The school nurse provides information to the family and coordinates between the medical provider and the family. Ms. Token went so far as to say, "Some people argue that is above and beyond, but at the same time, if the child is missing school...He needs to be somewhere on a list.” Ms. Token also indicated the school would facilitate the enrollment of the student in Kid Care; a form of insurance provided to low income families to ensure adequate health care.

Mr. Lone indicated the local hospital in his community provides health services to students with a medical card if they gain access by going to the Emergency Room. His nurse was also instrumental in identifying needy students and referring them to the appropriate outside agency. He and his staff would refer students and their families to the local health department for additional resources. 
Knowing about all the services available to homeless students and their families is cumbersome. The only way to ensure all principals are aware of the services available in to homeless students is through educating the principals.

\section{Research Question 2: What training do administrators have on the services available to homeless students?}

The interviews provided feedback on administrator training on the services available to homeless students. This feedback revealed three types of training. Training provided through certification programs (university course work), local ROE meetings, and the recertification process provided by Illinois Principal Association (IPA) or ISBE.

\section{Certification Programs}

Principals receive their certification through an accredited university. Every program requires principals to study school law and the Illinois School code. Only two of the participants mentioned receiving training on the McKinney Vento Homeless Act through their certification process. Ms. Token and Mr. Enright both recalled the Act being discussed in their legal coursework. Interestingly, both Ms. Token and Mr. Enright received their Master's degree and principal certification at Illinois State University. Since the researcher did not request the specific university for which the other two participants received their training, it would not be appropriate to speculate on their training. This issue will be further developed later in this paper when reviewing recommendations for further research. The ROE provides administrator meetings periodically throughout the year. 


\section{Regional Office of Education}

The McKinney Vento Act provides for the Illinois State Board of Education to implement the provisions of the Act. The ISBE has designated the local ROEs as the liaison responsible for disseminating the information to LEAs. The ROE conducts principal and superintendent meetings where federal mandates and state requirements are discussed. Through the document analysis aspect of this research project, the documents disseminated by the ISBE where obtained from the IKAN ROE. All of the participants indicated they had not received the information contained in documents received by the researcher. The common theme among the research participants was that at "some" meeting along the lines of their administrative career, they all recalled "hearing" that homeless students were to be immediately enrolled and receive certain services. Those services included free/reduced lunch, and transportation. The training also indicated that the student need NOT have all required enrollment papers to start attending. However, the required documentation should be presented at some point.

All principals shared there was a local homeless liaison appointed by their district to handle the enrollment of homeless students. The homeless liaison was trained by the ROE to facilitate the enrollment of the homeless youth and abide by the McKinney Vento Act, as well as the state requirements. Each principal was able to name the liaison and utilized the liaison when situations occurred involving homeless youth. Mr. Lone indicated his liaison was the middle school principal in his district. Mr. Enright indicated his district was unique in that he was both the principal and the superintendent. His additional coursework and training did provide him with knowledge the other three did not display. Mr. Enright further explained his experience in not only a past district, but a 
past ROE, "Now, when I was in the BHS ROE that [being homeless] was a pretty prominent point. I would say it was mentioned in almost every one of our meeting. Make sure you are identifying your homeless population." He also indicated his previous ROE provided forms for all principals to complete to track enrollment of homeless students.

Although each participant had their own opinion of the issues surrounding the enrollment of homeless students, none of them could provide documentation or evidence of training that could prepare them for the challenges to enrolling homeless youth.

\section{Research Question 3: What challenges are school administrators facing with the increasing population of homeless students?}

The participants shared a wide variety of challenges faced by principals. These challenges were categorized into three themes. These themes are identification, mobility, and relationships. All four principals agreed the identification was the most difficult aspect to enrolling homeless students.

\section{Identification}

There are two ways to identify homeless youth. The first is self-disclosure of the homeless situation by either the student or the youth parent/guardian. All participants indicated confidentiality and trust played an essential part to homeless people disclosing

their situation. Mr. Danik stated, "We would for sure respect the privacy of those students and their situation. But at the same time, in a discrete way letting them know that we're here (for them)." He continued by saying, "The biggest problem is defining who or determining who is homeless based on the definition or the criteria." Ms. Token also mentioned: 
It always surprises me when they aren't disclosing. I understand privacy and they don't want people to know, pride, their hardships. But we have things we can make available to them if we know that they are in a hardship situation.

Mr. Enright concurred, "The challenge is making sure they are homeless...There seemed to be so many ways in which someone could be called homeless that it was difficult to figure out what constitutes a homeless person." The confusion of the definition and requirements to for being homeless prevents these administrators from identifying students that do not disclose their living arrangements.

The second type of disclosure is when a staff member or counselor finds out that a family is living out of a vehicle or has moved in with a family member. This qualifies the person as homeless, but most people are offended when confronted by the term homeless. Ms. Token was the only person interviewed that indicated she and her staff would talk with the student about the living arrangements. Ms. Token explained,

We will hear rumors that they are living out of a van or something nearby. And we bring the student in and talk to them a little bit about it, but they don't disclose. And so until they disclose, it is kind of difficult for us to deal with it [homelessness].

The identification process whether it be self-disclosure or faculty acknowledging becomes extremely sensitive as indicated by Mr. Danik, Mr. Enright and Ms. Token. Mr. Lone did not list self-disclosure or faculty acknowledgement during his interview. He did refer to the mobility of the family as an indicator of homelessness when he talked about a family that carried all their documents in a rubber tub. Mr. Lone indicated this was a very organized set of documents for the children and he speculated that the family 
was very familiar with the enrollment process. This extensive knowledge relates to the family being in a continuous cycle of travel.

\section{Mobility}

The theme of mobility relates to the movement of homeless youth. The interviews revealed the difficulty of homeless individuals to maintain a consistent address within the boundaries of a school district. This affects the student's ability to attend school on a regular basis. All four administrators discussed the mobility rate of their homeless population in a variety of ways. Mr. Danik described a situation in which the student was attending school in his previous district. The family became homeless and went to live in a shelter outside the district. Residency laws would normally require that student to begin attending the neighboring district. By declaring themselves homeless, the student stayed in his school of origin. This allowed the student consistency in his educational environment with a very inconsistent home life.

Mr. Lone relayed the mobility as a factor in the student's education. He cited the student's lack of academic success to the disruption in their schooling when moved from school to school. He extended this by saying, "They're never in one place very long, it seems like. So there is no permanency in their head. And so everything is just temporary... they don't take advantage of [services]..."

Ms. Token merged the mobility with attendance by stating, "So, I half expect that they're going to take off within the next week or two as well. And this daughter, the younger sibling, has very, very poor attendance, also." She explained that part of the attendance issue is the child's fear that the family will move on while they are at school. The child's anxiety of losing the parent and not being able to find them prevents them 
from attending. The parent on the other hand has limited relationships with other people other than the children and allows the children to miss school to interact with the parent. Mr. Enright called the behavior "transient."

This behavior of moving from place to place is a result of no permanent living arrangement. The family must continue to move to avoid a variety of unpleasant situations. Some are avoiding altercations with family members, members of law enforcement, and social service agents. This mobility is described by all interviewees as a condition that supports the unstable educational environment of the child. The combination of lack of housing, poor attendance and the increased mobility of the family make it difficult for relationships to flourish.

\section{Relationships}

In schools, developing relationships is essential to the success of all students regardless of their home life. The affects relationships have on students is so vital to the overall development of the student and the school relationship, it will be discussed in two different ways for the purpose of this study. The first aspect is the relationship of the school to the child or his/her parent/guardian. The second will be addressed when discussing the development of the child in question number four. The overall relationship created when enrolling a homeless student in a school can be determined by the administration and staff. All four principals indicated they strive to develop meaningful relationships with all students' not just homeless students.

Each principal cited at least one member of their faculty they could call upon to try to develop a unique relationship with a student. Ms. Token talked about the after 
school programs available for students to gain knowledge beyond the classroom. One of those teachers was especially tolerant of children with special needs. Ms. Token stated:

And I think that [increasing tolerance] is key for some of these students, because that teacher cares. She is strict, but she is going to work them until she gets from them what she thinks they are capable of doing!

Mr. Enright clarified the relationship building as:

I would say that many, if not all cases that only one or two people might even now the student is homeless. That would be the administrator and the secretary. So, when staff sees these kids, they provide the same supports they would to any struggling kid.

Mr. Lone felt time was a factor when building a relationship with homeless students:

We try to get to know them as quick as possible ... that is probably in the back of everybody's mind in addressing those kids. I don't know that it affects things we are willing to do for them, but it is in the back of your head. So, I think maybe it adds pressure to try to get them involved and get them in the swing of things quickly.

This was echoed in Mr. Danik's comment:

I think if they had to go to the other district it probably wouldn't have worked out as well maybe for them. So, we knew that we were making a difference. Just in so far as peace-of-mind for mom, the boys liked being at our school.

The relationships established by the administrators and staff members' at all four schools show the ability of school districts to coordinate education and home life into a positive situation. This experience at school may be the only positive element in the student's life at that time. This experience aids in the overall development of the child and increases the possibility for students to be academically successful. 


\section{Research Question 4: What are the implications for homeless student learning and local education leaders with the increase in homeless students?}

The implications on student learning and local education leaders were described in four themes. All four revolve around four components of human development; social, emotional, educational, and physical. These components do not develop in isolation. It is the merging and layered development of each as the children progress that leads to a balanced life.

\section{Social}

The building of relationships is essential to human kind. We live in communities and work together to provide the essential elements of survival. Children in homeless situations often avoid developing friendships to minimize the emotional distress when they move on to a new location. Ms. Token described a situation in her school where she encouraged a homeless child to make friends and to become a part of the school. At one point the child became upset with her attempts to provide lunch partners and interactions with peers. Ms. Token stated:

...she didn't make friends. And I pulled her aside, and I said to her do you want me to introduce you to some other girls? And she said it's really not worth it, I won't be here that long anyways... she would be next to the girls, but not interacting with the girls ... It's just not worth it anymore, because I just know we are going to move out.... She came to school to escape the situation at home.

Developing the ability to trust other humans relates to the environment around us. Having a stable home life does not ensure a child will trust people, but it does establish the foundation for trusting relationships. Mr. Danik provided, “Parents don't want to be homeless. You know, so they are looking for, for someone they can trust, that security...." This holds true for students as well. Ms. Token relayed the student distrust 
of their own parents, "I think both the girls have concerns about who is going to be home when they get home." They worry that one or both parents may have taken off and leave them behind. This level of anxiety and distrust puts barriers on the child's emotional stability.

\section{Emotional}

This distrust and detachment of social situations relates to the emotional development of the homeless child. Mr. Enright described the homeless student difficulty making friends as a defense mechanism. "I think they are emotionally more volatile. So, they will quickly lose their temper and struggle to regaining composure." He described one homeless student, "One of the four was withdrawn from, just kind of society or had a very quiet, timid personality, or outlook on life.” Mr. Enright relayed how schools play an essential role in the development of students:

Because what happens is schools work hard to making sure kids are successful while they're in school. But as we have already noted, the mobility rate among homeless is higher. The academic achievements probably lower. And the social wellness, and social achievement or whatever you want to call it, social/emotional learning, is more of a challenge and we know from thousands of years of observation that if you have a supportive home life, it really gives kids a boost! So, schools are going to continue to work hard to try and serve kids when they are at school.

Mr. Enright indicated when the emotional development develops into mental health issues they refer the student or parent to the county health department. Ms. Token, Mr. Danik and Mr. Lone indicated they have utilized the county health department for emotional disorders as well.

The emotional development coupled with a fast maturity level also hinders the child's ability to relate to age appropriate educational material. 


\section{Educational}

The educational development of a child comes not only from school, but it comes from establishing an environment where learning is encouraged and expected. Homeless youth are not provided educational opportunities. Mr. Danik talked about the child's aptitude:

Even if learning is significantly enough, if they just haven't had exposure to education for whatever reason their homeless, you know, we know we are going to have to start the ball rolling.... We will have to determine where they are at academically and why is it that they are there?

The participants cited several reasons for a child being behind academically. Those reasons included lack of enrollment, lack of regular attendance, learning disability, parents without the mental capacity to assist in the child's education, or the lack of a place to complete homework on a regular basis. Any one of these elements can deter a child's progress academically, but the combination of these elements with the stress of not having a fixed residence only compounds the situation. The exact reason for lack of academic achievement may not be determined. When talking about one of her homeless situations, Ms. Token stated, “... she is mentally capable of learning the material. But she hasn't had the experience or the education to get her to grade level, yet."

Each administrator talked about providing Special Education support to students in a homeless situation. Although no student automatically qualifies for special services, all administrators indicated they would expedite an evaluation to determine if a child needs services in order to better serve that child.

Mr. Lone extended this to the student actually being at a disadvantage because of the lack of educational support: 
Well, it is enormously disruptive and puts the student at a disadvantage. If they don't have a regular night time residence, then they are probably not in a structured environment that is conducive to learning. The focus is not on education. The focus is on surviving. There is nothing stable in their life and learning takes a back seat. And it is just perpetuating a cycle of poverty.

Mr. Lone connected the educational aspect and the social aspect by explaining:

We view the athletics and activities as an extension of the educational day and is very important ... studies, for however they have been studying, all show that kids do better and are a lower risk for drop out [if involved] ... they [homeless students] are usually too worried about where their next meal is coming from to be able to spend time after school ... But they just tend not to be involved, no matter how hard our teachers and coaches try to get them involved. There is so much impermanence, we have had people move in and do all the paper work and leave within a week ... It is just a cycle of change for them.

The participants also agreed the education received by the student will be more of a "street smarts" realm. The student may be able to locate a place to sleep for the night, but be unable to read. Although the lack of experiences adversely affects the education of homeless youth, the constant lack of nutrition and emotional strain often presents as a physical ailment.

\section{Physical}

Each administrator discussed the importance of students receiving the free and reduced lunch program. The each had their own unique way of relating the nutrition to the learning process. Mr. Enright felt, “...they mature a lot quicker both physically, I think, and mentally."

Ms. Token looked at the nutritional aspect of development. She stated, "They can't stay awake. They are hungry and that affects their ability to learn when they're in the classroom." She also looked at the physical side as a possible medical condition. She insisted that a child with a tooth ache could not function adequately either on Tylenol or 
with the pain. To make learning significantly more productive, the children need consistent and adequate medical care as well as good nutrition. Mr. Danik listed the lunch program as a service provided in his district, but did not expand on the effects of hunger as it relates to student achievement.

All four aspects of development cannot be looked at separately. Thus, we must be able to look at the entire development of the child. In the homeless life style, too many factors are adversely affecting the positive development of the social, emotional, educational, and physical development of the child. Mr. Enright relayed it best, “... social/emotional learning is more of a challenge and we know from thousands of years of observation that if you have a supportive home life, it really gives kids a boost!"

\section{Summary}

The interviews and the documents analyzed produced themes for each of the four research questions posed at the onset of the qualitative study. The study reveals that schools are providing minimal services to address student needs. The rural setting appears to lack the appropriate social service agencies to service the homeless population existing there. The results showed consistency among administrators in regards to the training each has received to identify and enroll homeless students. The challenges faced by all participants were consistent to reveal additional needs of both homeless youth and the school districts that serve them. The effects on student learning are significant. Student success in the educational environment is a huge factor in alleviating homelessness. The McKinney Vento Homeless Act can only provide guidance to all social agencies that serve children. The essential aspect will be the ability of the school 
district where the child is educated being able to develop a relationship that promotes the social, emotional, educational, and physical development of the child. 


\section{CHAPTER VII}

\section{CONCLUSIONS, RECOMMENDATIONS, AND SUMMARY \\ Section 1: Conclusions and Implications}

Many people do not understand the relevance of homelessness to education.

Students living without a fixed night time residency struggle academically. Early in the literature review, information was provided to show how this population grew and changed over a few decades in the nineteenth century. Homeless youth are more likely to change schools, be absent, need and/or receive special education services due to a lack of consistent education within a single school system, and experience health related issues (both physical and mental) (Rossi, 1991; Berkowitz, 2002; O’Brien, 2008; Lagana \& Hubley, 2010). This combination of external factors makes learning difficult at best! As an educator, I believe it is my duty to provide the opportunity for all students to excel. Reviewing social issues, such as homelessness can only enhance my knowledge and allow me to better understand the needs of homeless youth. Once I understand the social issues that contribute to homelessness, I may be able to find resource(s) for students to minimize the affect homelessness has on their education.

To date, numerous advocacy groups have developed to promote legislation and public awareness of homeless. Since the implementation of the McKinney-Vento Act in 1987, little has been accomplished in rectifying the causes of homelessness. Specifically, legislation fails to address the gap between wages and affordable housing. The legislation 
provides for school personnel to ensure enrollment, provide supplies and meals while the student is in attendance, offer programs to address deficits in academic skills, support emotional counseling, and reduce other effects due to a lack of a permanent night time residence. However, the legislation does not address housing needs or prevent the loss of housing for families.

\section{Section 2: Recommendations for Future Research}

Data being collected by states to receive federal funding shows an increase in homeless children. Is this growth due to families become homeless due to economic conditions or due to the growing knowledge of educators and service providers to the definition provided in the McKinney-Vento legislation? These questions along with identifying the ever changing causes to youth homelessness continue to provide opportunities for educational research. This will continue the need for conducting integrated policy analysis of the McKinney-Vento Homeless Act. The research conducted here will provide a background for future studies.

The qualitative study included in this research provided answers to four research questions, but also brought to light other areas in need of future research. First, research should be conducted to determine the training opportunities available for practicing administrators. Research should include reviewing administrator preparation programs to determine what (if any) information is being provided to aspiring principals on the requirements and procedures to effectively implement the McKinney-Vento Homeless Act. The information obtained from that research could be utilized to expand opportunities for principals to provide additional services within their district. 
Another area of research regarding training is the information provided by the Regional Office of Education (ROE). Research needs to be conducted to determine who is receiving the training from the ROE and how those individuals are disseminate the information they obtain on enrollment procedures and services available to homeless students to other staff members in their district.

The Illinois State Board of Education (ISBE) in conjunction with the Illinois Interactive Report Card (IIRC) is collecting data on school districts. This data is extensive, and yet, does not include any information about the homeless population of the district. The homeless population is only included in the free and/or reduced lunch program category. A separate category for the homeless population would provide a means to collect quantitative data and determine shifts in the homeless population across the state. This information would be vital to researchers looking to study principal participation in the enrollment procedures and services offered to homeless students. The researcher could utilize purposeful sampling and identify homeless populations.

Another area of research that has not been reviewed is the perceptions of the staff members of districts with homeless students. Walsh and Buckley (1994) studied the perceptions of counselors on the enrollment procedures and services available to homeless youth. However, the school nurse, teachers and other district employees have had limited participation in the research of the enrollment process. Research has also been conducted to identify barriers to enrollment, but the perceptions and experiences of the staff in charge of enrolling these families have not been investigated in Illinois.

Each administrator interviewed discussed "the cost" to the district of having homeless students enrolled. The McKinney-Vento Homeless Act has been underfunded 
since it was authorized in 1987. Research should be conducted to determine the financial responsibility of a school district once a student is identified as homeless. This data should include but not be limited to evaluating the system of delivery of services and changes in school employee job duties. For instance, the free and/or reduced lunch program is not exclusive to the homeless population. However, looking at the proportion of homeless students in comparison to other students receiving free and/or reduced lunch may provide additional data for evaluating necessary health related programs to both students and parents.

The constantly changing definition of homeless and the increase in the homeless population has created a variety of social issues for investigation. This study has linked Bloom's Taxonomy to the academic achievement of homeless youth. Additional research could reveal more information to reduce the homeless population and/or increase student achievement for the students who continue to live under the definition of homeless and meet the qualifications as defined in the McKinney-Vento Act.

Homelessness has affected Americans since Columbus settled in America. The definition has evolved over time to mirror societies attempt at social justice. Homelessness during colonization was lacking a house or shelter (Berkowitz, 2002). Merriam-Webster's online dictionary (2010) defined homeless as "having no home or permanent place of residence." The homeless definition authorized by the McKinney-Vento Education for Homeless Children and Youth Act of 2001 stated:

The term "homeless children and youths"-

(A) means individuals who lack a fixed, regular, and adequate nighttime residence (within the meaning of section 11302 (a) (1) of this title); and (B) includes- 
(i) children and youths who are sharing the housing of other persons due to loss of housing, economic hardship, or a similar reason; are living in motels, hotels, trailer parks, or camping grounds due to the lack of alternative adequate accommodations; are living in emergency or transitional shelters; are abandoned in hospitals; or are awaiting foster care placement;

(ii) children and youths who have a primary nighttime residence that is a public or private place not designed for or ordinarily used as a regular sleeping accommodation for human beings (within the meaning of section 11302 (a)(2)(C) ${ }^{[1]}$ of this title); (iii) children and youths who are living in cars, parks, public spaces, abandoned buildings, substandard housing, bus or train stations, or similar settings; and

(iv) migratory children (as such term is defined in section $\underline{6399}$ of title 20) who qualify as homeless for the purposes of this part because the children are living in circumstances described in clauses (i) through (iii).

The original language defining homeless included terms such as trailer park. The new language clarified this term to exclude mobile home parks. However, short term camping parks which allow people to rent by the night are considered temporary housing and would qualify a person as homeless if this was their only housing. The courts and reauthorizations of the legislation have broadened the homeless term and taken into consideration the unique situations experienced by homeless children today. The natural disasters like Hurricane Katrina, economic down turn like the closing automobile plants, and general loss of jobs has required Americans to double up their housing situations (live with others due to economic hardship). In all of these situations, children are considered homeless.

The recent enactment of the Homeless Bill of Rights will provide an additional opportunity for research. The connection between maintaining employment and lacking housing could be the social change necessary to make a significant difference in any life. 
Tracking and identifying the homeless continues to be the most difficult aspect of researching the causes of homelessness and barriers to alleviating homelessness.

\section{Section 3: Summary}

The McKinney-Vento Act provides provisions for school districts to alleviate some of the effects of homelessness on school age children. Sadly, the provisions are not consistently and equitable dispersed among all school districts across the nation. In response to compulsory education laws and social justice principles, legislators continue to propose changes to the McKinney-Vento Act and other legislation designed to raise overall student achievement. The premise is well intended. The primary barrier to resolving the issues of educating homeless youth is not the educational system, but the failure to provide affordable housing to families.

The only way to resolve the issues of homelessness is to resolve the housing issue. The McKinney-Vento Act will need to remain a guide to school districts to reduce the effects on educating homeless youth until society can resolve the housing shortage. 


\section{REFERENCES}

Ableidinger, J. D. (2004, Fall). Educational Rights of Homeless Children and Youths:

The McKinney-Vento Act and Its Impact on North Carolina's Schools. School Law Bulletin, Retrieved April 20, 2014 from http://sogpubs.unc.edu.

Arizona Department of Education (2014). K-12 Academic Standards. Retrieved March 1, 2014, from www.azed.gov/standards-practices.

Berkowitz, A. B. (2002, Winter). Homeless Children Dream of College Too: The Struggle to Provide America's Homeless Youth With a Viable Education [Review of 31 Hofstra L. Rev. 515]. Hofstra Law Review, 2-34. Retrieved June 2, 2009, from LexisNexis.

Black, D. W. (2008, Spring). Note \& Comment: Education Law Mini-Symposium: Leave No Child Out: An Introduction to Homelessness, Joblessness, and Bullying in America's Schools. [Review of 51 Howard Law Journal 765]. Retrieved July 16, 2010 from LexisNexis.

Brody, Robert G., and Rebecca Goldberg. "Is Homelessness the next Protected Class?" Brody \& Associates: Legal Updates (2013). 1 July 2014. http://brodyandassociates.com/is-homelessness-the-next-protected-class.

Community Health Care Act. (2013). Retrieved April 20, 2014, from http://www.thenationalcouncil.org/

Duffield, B. (2010, November 8). What's hot and what's not: A federal policy update. Speech presented at National Association for the Education of Homeless Children and Youth 22nd Annual Conference, Houston, TX. Retrieved from www.naehcy.org/conf/dl/2010/duffield_fed.ppt

Dunn, W. N. (2011). Public Policy Analysis (5 $5^{\text {th }}$ ed.). Englewood Cliffs, N.J.: PrenticeHall.

"Elementary and Secondary Education Act of 1965." Major Acts of Congress. Ed. Brian K. Landsberg. Macmillan-Thomson Gale, 2004. eNotes.com. 2006. Retrieved July 30, 2009 from http://www.enotes.com/major-acts-congress/elementarysecondary-education-act 
Fortino, E. (2013, August 27). Illinois enacts landmark Homeless Bill of Rights. Retrieved July 1, 2014, from http://progressillinois.com.

Heybach, L. M. (2009). Advocacy and Obstacles in the Education of Homeless Children and Youth in Illinois. Public Interest Law Reporter, 14(3), 8. Retrieved from www.luc.edu/law/student/publications/pilr/vol14_no3.html.

homeless. (2010). In Merriam-Webster Online Dictionary. Retrieved June 11, 2010, from http://www.merriam-webster.com/dictionary/homeless

Illinois State Board of Education. (n.d.). Illinois Education for Homeless Children Act. Retrieved July 31, 2009, from http://www.homelessed.net/legislat/ILLINOIS.htm

Jimmy Carter: "Mental Health Systems Legislation Message to the Congress Transmitting the Proposed Legislation." May 15, 1979. Online by Gerhard Peters and John T. Woolley, The American Presidency Project. http://www.presidency.ucsb.edu/ws/?pid=32339.

Lagana, J. \& Hubley, N. (2010) Homeless Kids need good schooling: And efforts are under way in Allegheny County to make sure they get it. Pittsburg's Post-Gazette. Retrieved June 8, 2010 from http://www.post-gazette.com

The McKinney-Vento Homeless Assistance Act. (n.d.). Retrieved June 11, 2014, from http://center.serve.org/nche/legis/mv.php

Merriam, S. B., (2009). Qualitative research: A guide to design and implementation. San Francisco, CA: Jossey-Bass.

Na, J. A. (2008, Spring). 51 How. L.J 863. Retrieved June 2, 2009, from LexisNexis.

Obiakor, F. E. \& Wilder, L.K. (2003) Disproportionate Representation in Special Education. Principal Leadership, v9 n2, 9-16. Retrieved June 8, 2010.

O’Brien, J. C. (2008, April) Loose Standards, Tight Lips: Why Easy Access to Client Data Can Undermine Homeless Management Information Systems [Review of 35 Fordham Urban L.J. 673]. Fordham Urban Law Journal, 1-24. Retrieved May 19, 2009, from LexisNexis.

O'Leary, S. (2001, Summer). Hot Topics in Education: Educating Homeless Children [Review of 8 Geo. J. Poverty Law \& Pol'y 513]. Georgetown Journal on Poverty Law \& Policy, 2-7. Retrieved June 2, 2009, from LexisNexis.

Petersburg, B. (2008, Fall). Current Public Law and Policy Issues: Reconciling the McKinney-Vento Act with the Vision of the Universal Declaration of Human rights: Improving Local Educational Agency Liaisons' Ability to Serve America's 
Homeless Children. [Review of 30 Hamline J. Pub. L. \& Pol'y 447]. Retrieved July 16, 2010 from LexisNexis.

Powell Crain, T. (2014, January 31). Homeless Students' Federal Court Case Here Could Impact Children Nationwide. Alabama School Connection.org. Retrieved June 11, 2014, from http://alabamaschoolconnection.org/2014/01/31/homeless-studentsfederal-court-case-here-could-impact-children-nationwide/

Rossi, P. H. (1991). Down and Out in America The Origins of Homelessness. New York: University Of Chicago P.

Salazar v. Edwards, 92 CH 5703 (Cir. ct. of Cook Co., IL 2000) Civil Rights Litigation Clearinghouse. (2006, June 06). Retrieved July 16, 2010, from http://www.clearinghouse.net/detail.php?id=2.

Schwartz, B. D. \& Day, S. L. (2012) Illinois Law in the School Office: The Essential Desk Reference. Springfield, IL: Illinois Principals Association.

Slater, D.J. (2006, January 26). A Reversal On Aid for Homeless; Schools to Request Federal Funding. Washington Post. Retrieved from http://www.lexisnexis.com.proxy.lib.ilstu.edu

Spring, J. (2004). Conflict of Interests: The politics of American education. $5^{\text {th }}$ edition. $\mathrm{OH}:$ McGraw-Hill.

Stephenie Bullock, et al. v. Board of Education of Montgomery County, et al. (2002, November 4). Retrieved June 2, 2009, from http://www-lexisnexiscom.proxy.lib.ilstu.edu/us/Inacademic

Trattner, W. I. (1993). From Poor Law to Welfare State: A history of social welfare in America. $5^{\text {th }}$ edition. New York: The Free Press.

United States, United States Department of Education, Washington, DC. (2004, September 15) Elementary and Secondary Education Part $C-$ Homeless Education. Retrieved April 27, 2014, from http://www2.ed.gov/policy/elsec/leg/esea02/pg116.html

United States, United States Department of Education, Washington, DC. (2004, July). Education for Homeless Children and Youth Program. Retrieved June 2, 2009, from http://www.ed.gov/programs/homeless/guidance.pdf

United States, United States Department of Housing and Urban Development, Washington, DC. (2009, July). The 2008 Annual Homeless Assessment Report. Retrieved June 19, 2010, from http://www.hudhre.info/documents/4thHomelessAssessmentReport.pdf 
Walsh, M., \& Buckley, M. (1994). Children's experiences of homelessness: Implications for school counselors. Elementary School Guidance \& Counseling, 29(1), 4. http://search.ebscohost.com on October 16, 2009.

Weber, C. (2009) Homeless Student Enrollment and Services Offered in Illinois School. A Qualitative Research Study at Illinois State University.

Weber, C. \& Lugg, E. (2008, October) McKinney-Vento Homeless Act: Theory into Practice. Paper presented at the Education Law Association National Convention on Education Law in a Time of Change: Federal, State, and Local Policy, Louisville, KY.

Wong, J., Salomon, A., Thistle Elliott, L., Tallarita, L., and Reed, S. (2004, Spring) $10^{\text {th }}$ Anniversary Symposium Issue: Empowering the Poor and Disenfranchised: Making a Difference Through Community, Advocacy, and Policy: Article: The McKinney-Vento Homeless Assistance Act-Education for Homeless Children and Youths Program: Turning Good Law into Effective Education. [Review of 11 Geo. J. Poverty Law \& Policy 283]. Retrieved July 16, 2010, from LexisNexis.

Wong, K. (2002). Federal Educational Policy as an Anti-Poverty Strategy. Notre Dame Journal of Law, Ethics, and Public Policy, 16(421). 
APPENDIX A

\section{MCKINNEY-VENTO EDUCATION FOR HOMELESS CHILDREN}

AND YOUTH ACT OF 2001

\section{U.S.C. $§ 11431$ - STATEMENT OF POLICY}

The following is the policy of the Congress:

(1) Each State educational agency shall ensure that each child of a homeless individual and each homeless youth have equal access to the same free, appropriate public education, including a public preschool education, as provided to other children and youths.

(2) In any State that has a compulsory residency requirement as a component of the State's compulsory school attendance laws or other laws, regulations, practices, or policies that may act as a barrier to the enrollment, attendance, or success in school of homeless children and youths, the State will review and undertake steps to revise such laws, regulations, practices, or policies to ensure that homeless children and youths are afforded the same free, appropriate public education as provided to other children and youths.

(3) Homelessness alone is not sufficient reason to separate students from the mainstream school environment.

(4) Homeless children and youths should have access to the education and other services that such children and youths need to ensure that such children and youths have an opportunity to meet the same challenging State student academic achievement standards to which all students are held.

\section{U.S.C. $\$ 11432$ - GRANTS FOR STATE AND LOCAL ACTIVITIES FOR THE EDUCATION OF HOMELESS CHILDREN AND YOUTHS}

(a) GENERAL AUTHORITY - The Secretary is authorized to make grants to States in accordance with the provisions of this section to enable such States to carry out the activities described in subsections (d) through (g) of this section.

(b) APPLICATION - No State may receive a grant under this section unless the State educational agency submits an application to the Secretary at such time, in such manner, and containing or accompanied by such information as the Secretary may reasonably require.

(c) ALLOCATION AND RESERVATIONS

(1) ALLOCATION - 
(A) Subject to subparagraph (B), the Secretary is authorized to allot to each State an amount that bears the same ratio to the amount appropriated for such year under section 11435 of this title that remains after the Secretary reserves funds under paragraph (2) and uses funds to carry out section 11434 (d) and (h) of this title, as the amount allocated under section 1122 of the Elementary and Secondary Education Act of 1965 [20 U.S.C. 6332] to the State for that year bears to the total amount allocated under section 1122 of such Act to all States for that year, except that no State shall receive less than the greater of-

(i) $\$ 150,000$;

(ii) one-fourth of 1 percent of the amount appropriated under section 11435 of this title for that year; or

(iii) the amount such State received under this section for fiscal year 2001.

(B) If there are insufficient funds in a fiscal year to allot to each State the minimum amount under subparagraph (A), the Secretary shall ratably reduce the allotments to all States based on the proportionate share that each State received under this subsection for the preceding fiscal year.

\section{(2) RESERVATIONS -}

(A) The Secretary is authorized to reserve 0.1 percent of the amount appropriated for each fiscal year under section 11435 of this title to be allocated by the Secretary among the United States Virgin Islands, Guam, American Samoa, and the Commonwealth of the Northern Mariana Islands, according to their respective need for assistance under this part, as determined by the Secretary.

(B)(i) The Secretary shall transfer 1 percent of the amount appropriated for each fiscal year under section 11435 of this title to the Department of the Interior for programs for Indian students served by schools funded by the Secretary of the Interior, as determined under the Indian SelfDetermination and Education Assistance Act (25 U.S.C. $\underline{450}$ et seq.), that are consistent with the purposes of the programs described in this part. (ii) The Secretary and the Secretary of the Interior shall enter into an agreement, consistent with the requirements of this part, for the distribution and use of the funds described in clause (i) under terms that the Secretary determines best meet the purposes of the programs described in this part. Such agreement shall set forth the plans of the Secretary of the Interior for the use of the amounts transferred, including appropriate goals, objectives, and milestones.

(3) STATE DEFINED - For purposes of this subsection, the term "State" does not include the United States Virgin Islands, Guam, American Samoa, or the Commonwealth of the Northern Mariana Islands.

(d) ACTIVITIES - Grants under this section shall be used for the following:

(1) To carry out the policies set forth in section 11431 of this title in the State.

(2) To provide activities for, and services to, homeless children, including preschool-aged homeless children, and youths that enable such children and 
youths to enroll in, attend, and succeed in school, or, if appropriate, in preschool programs.

(3) To establish or designate an Office of Coordinator for Education of Homeless Children and Youths in the State educational agency in accordance with subsection (f) of this section.

(4) To prepare and carry out the State plan described in subsection (g) of this section.

(5) To develop and implement professional development programs for school personnel to heighten their awareness of, and capacity to respond to, specific problems in the education of homeless children and youths.

\section{(e) STATE AND LOCAL SUBGRANTS}

(1) MINIMUM DISBURSEMENTS BY STATES - From the sums made available each year to carry out this part, the State educational agency shall distribute not less than 75 percent in subgrants to local educational agencies for the purposes of carrying out section 11433 of this title, except that States funded at the minimum level set forth in subsection (c)(1) of this section shall distribute not less than 50 percent in subgrants to local educational agencies for the purposes of carrying out section 11433 of this title.

(2) USE BY STATE EDUCATIONAL AGENCY - A State educational agency may use funds made available for State use under this part to conduct activities under subsection (f) of this section directly or through grants or contracts.

\section{(3) PROHIBITION ON SEGREGATING HOMELESS STUDENTS}

(A) IN GENERAL - Except as provided in subparagraph (B) and section 11433 (a)(2)(B)(ii) of this title, in providing a free public education to a homeless child or youth, no State receiving funds under this part shall segregate such child or youth in a separate school, or in a separate program within a school, based on such child's or youth's status as homeless.

(B) EXCEPTION - Notwithstanding subparagraph (A), paragraphs (1)(J)(i) and (3) of subsection (g) of this section, section 11433 (a)(2) of this title, and any other provision of this part relating to the placement of homeless children or youths in schools, a State that has a separate school for homeless children or youths that was operated in fiscal year 2000 in a covered county shall be eligible to receive funds under this part for programs carried out in such school if-

(i) the school meets the requirements of subparagraph (C);

(ii) any local educational agency serving a school that the homeless children and youths enrolled in the separate school are eligible to attend meets the requirements of subparagraph (E); and

(iii) the State is otherwise eligible to receive funds under this part.

(C) SCHOOL REQUIREMENTS - For the State to be eligible under subparagraph (B) to receive funds under this part, the school described in such subparagraph shall-

(i) provide written notice, at the time any child or youth seeks enrollment in such school, and at least twice annually while the child or youth is enrolled in such school, to the parent or guardian 
of the child or youth (or, in the case of an unaccompanied youth, the youth) that-

(I) shall be signed by the parent or guardian (or, in the case of an unaccompanied youth, the youth);

(II) sets forth the general rights provided under this part;

(III) specifically states-

(aa) the choice of schools homeless children and youths are eligible to attend, as provided in subsection $(\mathrm{g})(3)(\mathrm{A})$ of this section;

(bb) that no homeless child or youth is required to attend a separate school for homeless children or youths;

(cc) that homeless children and youths shall be provided comparable services described in subsection ( $\mathrm{g}$ )(4) of this section, including transportation services, educational services, and meals through school meals programs; and (dd) that homeless children and youths should not be stigmatized by school personnel; and

(IV) provides contact information for the local liaison for homeless children and youths and the State Coordinator for Education of Homeless Children and Youths;

(ii)(I) provide assistance to the parent or guardian of each homeless child or youth (or, in the case of an unaccompanied youth, the youth) to exercise the right to attend the parent's or guardian's (or youth's) choice of schools, as provided in subsection $(\mathrm{g})(3)(\mathrm{A})$ of this section; and

(II) coordinate with the local educational agency with jurisdiction for the school selected by the parent or guardian (or youth), to provide transportation and other necessary services;

(iii) ensure that the parent or guardian (or, in the case of an unaccompanied youth, the youth) shall receive the information required by this subparagraph in a manner and form understandable to such parent or guardian (or youth), including, if necessary and to the extent feasible, in the native language of such parent or guardian (or youth); and

(iv) demonstrate in the school's application for funds under this part that such school-

(I) is complying with clauses (i) and (ii); and

(II) is meeting (as of the date of submission of the application) the same Federal and State standards, regulations, and mandates as other public schools in the State (such as complying with sections 1111 and 1116 of the Elementary and Secondary Education Act of 1965 [20 U.S.C. $\underline{6311}, \underline{6316]}$ and providing a full range of education 
and related services, including services applicable to students with disabilities).

(D) SCHOOL INELIGIBILITY - A separate school described in subparagraph (B) that fails to meet the standards, regulations, and mandates described in subparagraph (C)(iv)(II) shall not be eligible to receive funds under this part for programs carried out in such school after the first date of such failure.

(E) LOCAL EDUCATIONAL AGENCY REQUIREMENTS - For the State to be eligible to receive the funds described in subparagraph (B), the local educational agency described in subparagraph (B)(ii) shall-

(i) implement a coordinated system for ensuring that homeless children and youths-

(I) are advised of the choice of schools provided in subsection $(\mathrm{g})(3)(\mathrm{A})$ of this section;

(II) are immediately enrolled, in accordance with subsection $(\mathrm{g})(3)(\mathrm{C})$ of this section, in the school selected under subsection $(\mathrm{g})(3)(\mathrm{A})$ of this section; and (III) are promptly provided necessary services described in subsection $(\mathrm{g})(4)$ of this section, including transportation, to allow homeless children and youths to exercise their choices of schools under subsection $(\mathrm{g})(3)(\mathrm{A})$ of this section;

(ii) document that written notice has been provided-

(I) in accordance with subparagraph (C)(i) for each child or youth enrolled in a separate school under subparagraph (B); and

(II) in accordance with subsection $(\mathrm{g})(6)(\mathrm{A})(\mathrm{v})$ of this section;

(iii) prohibit schools within the agency's jurisdiction from referring homeless children or youths to, or requiring homeless children and youths to enroll in or attend, a separate school described in subparagraph (B);

(iv) identify and remove any barriers that exist in schools within the agency's jurisdiction that may have contributed to the creation or existence of separate schools described in subparagraph (B); and (v) not use funds received under this part to establish-

(I) new or additional separate schools for homeless children or youths; or

(II) new or additional sites for separate schools for homeless children or youths, other than the sites occupied by the schools described in subparagraph (B) in fiscal year 2000.

\section{(F) REPORT -}

(i) Preparation The Secretary shall prepare a report on the separate schools and local educational agencies described in subparagraph

(B) that receive funds under this part in accordance with this 
paragraph. The report shall contain, at a minimum, information on-

(I) compliance with all requirements of this paragraph;

(II) barriers to school access in the school districts served by the local educational agencies; and

(III) the progress the separate schools are making in integrating homeless children and youths into the mainstream school environment, including the average length of student enrollment in such schools.

(ii) Compliance with information requests For purposes of enabling the Secretary to prepare the report, the separate schools and local educational agencies shall cooperate with the Secretary and the State Coordinator for Education of Homeless Children and Youths established in the State under subsection (d)(3) of this section, and shall comply with any requests for information by the Secretary and State Coordinator for such State.

(iii) Submission Not later than 2 years after January 8, 2002, the Secretary shall submit the report described in clause (i) to-

(I) the President;

(II) the Committee on Education and the Workforce of the House of Representatives; and

(III) the Committee on Health, Education, Labor, and Pensions of the Senate.

(G) DEFINITION - For purposes of this paragraph, the term "covered county" means-

(i) San Joaquin County, California;

(ii) Orange County, California;

(iii) San Diego County, California; and

(iv) Maricopa County, Arizona.

(f) FUNCTIONS OF THE OFFICE OF COORDINATOR - The Coordinator for Education of Homeless Children and Youths established in each State shall-

(1) gather reliable, valid, and comprehensive information on the nature and extent of the problems homeless children and youths have in gaining access to public preschool programs and to public elementary schools and secondary schools, the difficulties in identifying the special needs of such children and youths, any progress made by the State educational agency and local educational agencies in the State in addressing such problems and difficulties, and the success of the programs under this part in allowing homeless children and youths to enroll in, attend, and succeed in, school;

(2) develop and carry out the State plan described in subsection (g) of this section; (3) collect and transmit to the Secretary, at such time and in such manner as the Secretary may require, a report containing such information as the Secretary determines is necessary to assess the educational needs of homeless children and youths within the State;

(4) facilitate coordination between the State educational agency, the State social services agency, and other agencies (including agencies providing mental health 
services) to provide services to homeless children, including preschool-aged homeless children, and youths, and to families of such children and youths; (5) in order to improve the provision of comprehensive education and related services to homeless children and youths and their families, coordinate and collaborate withpersonnel;

(A) educators, including child development and preschool program

(B) providers of services to homeless and runaway children and youths and homeless families (including domestic violence agencies, shelter operators, transitional housing facilities, runaway and homeless youth centers, and transitional living programs for homeless youths);

(C) local educational agency liaisons designated under subsection (g)(1)(J)(ii) of this section for homeless children and youths; and

(D) community organizations and groups representing homeless children and youths and their families; and

(6) provide technical assistance to local educational agencies in coordination with local educational agency liaisons designated under subsection $(\mathrm{g})(1)(\mathrm{J})(\mathrm{ii})$ of this section, to ensure that local educational agencies comply with the requirements of subsection (e)(3) of this section and paragraphs (3) through (7) of subsection ( $\mathrm{g}$ ) of this section.

\section{(g) STATE PLAN}

(1) IN GENERAL - Each State shall submit to the Secretary a plan to provide for the education of homeless children and youths within the State. Such plan shall include the following:

(A) A description of how such children and youths are (or will be) given the opportunity to meet the same challenging State academic achievement standards all students are expected to meet.

(B) A description of the procedures the State educational agency will use to identify such children and youths in the State and to assess their special needs.

(C) A description of procedures for the prompt resolution of disputes regarding the educational placement of homeless children and youths. (D) A description of programs for school personnel (including principals, attendance officers, teachers, enrollment personnel, and pupil services personnel) to heighten the awareness of such personnel of the specific needs of runaway and homeless youths.

(E) A description of procedures that ensure that homeless children and youths who meet the relevant eligibility criteria are able to participate in Federal, State, or local food programs.

(F) A description of procedures that ensure that-

(i) homeless children have equal access to the same public preschool programs, administered by the State agency, as provided to other children in the State;

(ii) homeless youths and youths separated from the public schools are identified and accorded equal access to appropriate secondary education and support services; and 
(iii) homeless children and youths who meet the relevant eligibility criteria are able to participate in Federal, State, or local before- and after-school care programs.

(G) Strategies to address problems identified in the report provided to the Secretary under subsection (f)(3) of this section.

(H) Strategies to address other problems with respect to the education of homeless children and youths, including problems resulting from enrollment delays that are caused by-

(i) immunization and medical records requirements;

(ii) residency requirements;

(iii) lack of birth certificates, school records, or other documentation;

(iv) guardianship issues; or

(v) uniform or dress code requirements.

(I) A demonstration that the State educational agency and local

educational agencies in the State have developed, and shall review and

revise, policies to remove barriers to the enrollment and retention of homeless children and youths in schools in the State.

(J) Assurances that-

(i) the State educational agency and local educational agencies in

the State will adopt policies and practices to ensure that homeless children and youths are not stigmatized or segregated on the basis of their status as homeless;

(ii) local educational agencies will designate an appropriate staff person, who may also be a coordinator for other Federal programs, as a local educational agency liaison for homeless children and youths, to carry out the duties described in paragraph (6)(A); and

(iii) the State and its local educational agencies will adopt policies and practices to ensure that transportation is provided, at the request of the parent or guardian (or in the case of an unaccompanied youth, the liaison), to and from the school of origin, as determined in paragraph (3)(A), in accordance with the following, as applicable:

(I) If the homeless child or youth continues to live in the area served by the local educational agency in which the school of origin is located, the child's or youth's transportation to and from the school of origin shall be provided or arranged by the local educational agency in which the school of origin is located.

(II) If the homeless child's or youth's living arrangements in the area served by the local educational agency of origin terminate and the child or youth, though continuing his or her education in the school of origin, begins living in an area served by another local educational agency, the local educational agency of origin and the local educational agency in which the homeless child or youth is living shall agree upon a method to apportion the responsibility 


\section{(2) COMPLIANCE}

and costs for providing the child with transportation to and from the school of origin. If the local educational agencies are unable to agree upon such method, the responsibility and costs for transportation shall be shared equally.

(A) IN GENERAL - Each plan adopted under this subsection shall also describe how the State will ensure that local educational agencies in the State will comply with the requirements of paragraphs (3) through (7).

(B) COORDINATION - Such plan shall indicate what technical assistance the State will furnish to local educational agencies and how compliance efforts will be coordinated with the local educational agency liaisons designated under paragraph (1)(J)(ii).

\section{(3) LOCAL EDUCATIONAL AGENCY REQUIREMENTS}

(A) In general - The local educational agency serving each child or youth to be assisted under this part shall, according to the child's or youth's best interest-

(i) continue the child's or youth's education in the school of origin for the duration of homelessness-

(I) in any case in which a family becomes homeless between academic years or during an academic year; or (II) for the remainder of the academic year, if the child or youth becomes permanently housed during an academic year; or

(ii) enroll the child or youth in any public school that nonhomeless students who live in the attendance area in which the child or youth is actually living are eligible to attend.

(B) BEST INTEREST - In determining the best interest of the child or youth under subparagraph (A), the local educational agency shall-

(i) to the extent feasible, keep a homeless child or youth in the school of origin, except when doing so is contrary to the wishes of the child's or youth's parent or guardian;

(ii) provide a written explanation, including a statement regarding the right to appeal under subparagraph (E), to the homeless child's or youth's parent or guardian, if the local educational agency sends such child or youth to a school other than the school of origin or a school requested by the parent or guardian; and

(iii) in the case of an unaccompanied youth, ensure that the homeless liaison designated under paragraph (1)(J)(ii) assists in placement or enrollment decisions under this subparagraph, considers the views of such unaccompanied youth, and provides notice to such youth of the right to appeal under subparagraph (E).

\section{(C) ENROLLMENT}

(i) The school selected in accordance with this paragraph shall immediately enroll the homeless child or youth, even if the child or youth is unable to produce records normally required for 
enrollment, such as previous academic records, medical records, proof of residency, or other documentation.

(ii) The enrolling school shall immediately contact the school last attended by the child or youth to obtain relevant academic and other records.

(iii) If the child or youth needs to obtain immunizations, or immunization or medical records, the enrolling school shall immediately refer the parent or guardian of the child or youth to the local educational agency liaison designated under paragraph (1)(J)(ii), who shall assist in obtaining necessary immunizations, or immunization or medical records, in accordance with subparagraph (D).

(D) RECORDS - Any record ordinarily kept by the school, including immunization or medical records, academic records, birth certificates, guardianship records, and evaluations for special services or programs, regarding each homeless child or youth shall be maintained-

(i) so that the records are available, in a timely fashion, when a child or youth enters a new school or school district; and

(ii) in a manner consistent with section $1232 \mathrm{~g}$ of title 20 .

(E) ENROLLMENT DISPUTES - If a dispute arises over school selection or enrollment in a school-

(i) the child or youth shall be immediately admitted to the school in which enrollment is sought, pending resolution of the dispute;

(ii) the parent or guardian of the child or youth shall be provided with a written explanation of the school's decision regarding school selection or enrollment, including the rights of the parent, guardian, or youth to appeal the decision;

(iii) the child, youth, parent, or guardian shall be referred to the local educational agency liaison designated under paragraph (1)(J)(ii), who shall carry out the dispute resolution process as described in paragraph $(1)(\mathrm{C})$ as expeditiously as possible after receiving notice of the dispute; and

(iv) in the case of an unaccompanied youth, the homeless liaison shall ensure that the youth is immediately enrolled in school pending resolution of the dispute.

(F) PLACEMENT CHOICE - The choice regarding placement shall be made regardless of whether the child or youth lives with the homeless parents or has been temporarily placed elsewhere.

(G) SCHOOL OF ORIGIN DEFINED - In this paragraph, the term "school of origin" means the school that the child or youth attended when permanently housed or the school in which the child or youth was last enrolled.

(H) CONTACT INFORMATION - Nothing in this part shall prohibit a local educational agency from requiring a parent or guardian of a homeless child to submit contact information. 
(4) COMPARABLE SERVICES - Each homeless child or youth to be assisted under this part shall be provided services comparable to services offered to other students in the school selected under paragraph (3), including the following:

(A) Transportation services.

(B) Educational services for which the child or youth meets the eligibility criteria, such as services provided under title I of the Elementary and Secondary Education Act of 1965 [20 U.S.C. $\underline{6301}$ et seq.] or similar State or local programs, educational programs for children with disabilities, and educational programs for students with limited English proficiency.

(C) Programs in vocational and technical education.

(D) Programs for gifted and talented students.

(E) School nutrition programs.

\section{(5) COORDINATION}

(A) IN GENERAL - Each local educational agency serving homeless children and youths that receives assistance under this part shall coordinate-

(i) the provision of services under this part with local social services agencies and other agencies or programs providing services to homeless children and youths and their families, including services and programs funded under the Runaway and Homeless Youth Act (42 U.S.C. 5701 et seq.); and (ii) with other local educational agencies on interdistrict issues, such as transportation or transfer of school records.

(B) HOUSING ASSISTANCE - If applicable, each State educational agency and local educational agency that receives assistance under this part shall coordinate with State and local housing agencies responsible for developing the comprehensive housing affordability strategy described in section $\underline{12705}$ of this title to minimize educational disruption for children and youths who become homeless.

(C) COORDINATION PURPOSE - The coordination required under subparagraphs (A) and (B) shall be designed to-

(i) ensure that homeless children and youths have access and reasonable proximity to available education and related support services; and

(ii) raise the awareness of school personnel and service providers of the effects of short-term stays in a shelter and other challenges associated with homelessness.

\section{(6) LOCAL EDUCATIONAL AGENCY LIAISON}

(A) DUTIES - Each local educational agency liaison for homeless children and youths, designated under paragraph (1)(J)(ii), shall ensure that-

(i) homeless children and youths are identified by school personnel and through coordination activities with other entities and agencies; 
(ii) homeless children and youths enroll in, and have a full and equal opportunity to succeed in, schools of that local educational agency;

(iii) homeless families, children, and youths receive educational services for which such families, children, and youths are eligible, including Head Start and Even Start programs and preschool programs administered by the local educational agency, and referrals to health care services, dental services, mental health services, and other appropriate services;

(iv) the parents or guardians of homeless children and youths are informed of the educational and related opportunities available to their children and are provided with meaningful opportunities to participate in the education of their children;

(v) public notice of the educational rights of homeless children and youths is disseminated where such children and youths receive services under this chapter, such as schools, family shelters, and soup kitchens;

(vi) enrollment disputes are mediated in accordance with paragraph (3)(E); and

(vii) the parent or guardian of a homeless child or youth, and any unaccompanied youth, is fully informed of all transportation services, including transportation to the school of origin, as described in paragraph (1)(J)(iii), and is assisted in accessing transportation to the school that is selected under paragraph (3)(A). (B) NOTICE - State coordinators established under subsection (d)(3) of this section and local educational agencies shall inform school personnel, service providers, and advocates working with homeless families of the duties of the local educational agency liaisons.

(C) LOCAL AND STATE COORDINATION - Local educational agency liaisons for homeless children and youths shall, as a part of their duties, coordinate and collaborate with State coordinators and community and school personnel responsible for the provision of education and related services to homeless children and youths.

\section{(7) REVIEW AND REVISIONS}

(A) IN GENERAL - Each State educational agency and local educational agency that receives assistance under this part shall review and revise any policies that may act as barriers to the enrollment of homeless children and youths in schools that are selected under paragraph (3).

(B) CONSIDERATION - In reviewing and revising such policies, consideration shall be given to issues concerning transportation, immunization, residency, birth certificates, school records and other documentation, and guardianship.

(C) SPECIAL ATTENTION - Special attention shall be given to ensuring the enrollment and attendance of homeless children and youths who are not currently attending school. 


\section{U.S.C. § 11433 - LOCAL EDUCATIONAL AGENCY SUBGRANTS FOR THE EDUCATION OF HOMELESS CHILDREN AND YOUTHS}

\section{(a) GENERAL AUTHORITY}

(1) IN GENERAL - The State educational agency shall, in accordance with section $\underline{11432}$ (e) of this title, and from amounts made available to such agency under section 11435 of this title, make subgrants to local educational agencies for the purpose of facilitating the enrollment, attendance, and success in school of homeless children and youths.

(2) SERVICES

(A) IN GENERAL - Services under paragraph (1) -

(i) may be provided through programs on school grounds or at other facilities;

(ii) shall, to the maximum extent practicable, be provided through existing programs and mechanisms that integrate homeless children and youths with nonhomeless children and youths; and (iii) shall be designed to expand or improve services provided as part of a school's regular academic program, but not to replace such services provided under such program.

(B) SERVICES ON SCHOOL GROUNDS - If services under paragraph

(1) are provided on school grounds, schools-

(i) may use funds under this part to provide the same services to other children and youths who are determined by the local educational agency to be at risk of failing in, or dropping out of, school, subject to the requirements of clause (ii); and (ii) except as otherwise provided in section 11432 (e)(3)(B) of this title, shall not provide services in settings within a school that segregate homeless children and youths from other children and youths, except as necessary for short periods of time-

(I) for health and safety emergencies; or

(II) to provide temporary, special, and supplementary services to meet the unique needs of homeless children and youths.

(3) REQUIREMENT - Services provided under this section shall not replace the regular academic program and shall be designed to expand upon or improve services provided as part of the school's regular academic program.

(b) APPLICATION - A local educational agency that desires to receive a subgrant under this section shall submit an application to the State educational agency at such time, in such manner, and containing or accompanied by such information as the State educational agency may reasonably require. Such application shall include the following:

(1) An assessment of the educational and related needs of homeless children and youths in the area served by such agency (which may be undertaken as part of needs assessments for other disadvantaged groups).

(2) A description of the services and programs for which assistance is sought to address the needs identified in paragraph (1). 
(3) An assurance that the local educational agency's combined fiscal effort per student, or the aggregate expenditures of that agency and the State with respect to the provision of free public education by such agency for the fiscal year preceding the fiscal year for which the determination is made, was not less than 90 percent of such combined fiscal effort or aggregate expenditures for the second fiscal year preceding the fiscal year for which the determination is made.

(4) An assurance that the applicant complies with, or will use requested funds to comply with, paragraphs (3) through (7) of section $11432(\mathrm{~g})$ of this title.

(5) A description of policies and procedures, consistent with section 11432 (e)(3) of this title, that the agency will implement to ensure that activities carried out by the agency will not isolate or stigmatize homeless children and youths.

\section{(c) AWARDS}

(1) IN GENERAL - The State educational agency shall, in accordance with the requirements of this part and from amounts made available to it under section 11435 of this title, make competitive subgrants to local educational agencies that submit applications under subsection (b) of this section. Such subgrants shall be awarded on the basis of the need of such agencies for assistance under this part and the quality of the applications submitted.

(2) NEED - In determining need under paragraph (1), the State educational agency may consider the number of homeless children and youths enrolled in preschool, elementary, and secondary schools within the area served by the local educational agency, and shall consider the needs of such children and youths and the ability of the local educational agency to meet such needs. The State educational agency may also consider the following:

(A) The extent to which the proposed use of funds will facilitate the enrollment, retention, and educational success of homeless children and youths.

(B) The extent to which the application-

(i) reflects coordination with other local and State agencies that serve homeless children and youths; and

(ii) describes how the applicant will meet the requirements of section $11432(\mathrm{~g})(3)$ of this title.

(C) The extent to which the applicant exhibits in the application and in current practice a commitment to education for all homeless children and youths.

(D) Such other criteria as the State agency determines appropriate.

(3) QUALITY - In determining the quality of applications under paragraph (1), the State educational agency shall consider the following:

(A) The applicant's needs assessment under subsection (b)(1) of this section and the likelihood that the program presented in the application will meet such needs.

(B) The types, intensity, and coordination of the services to be provided under the program.

(C) The involvement of parents or guardians of homeless children or youths in the education of their children. 
(D) The extent to which homeless children and youths will be integrated within the regular education program.

(E) The quality of the applicant's evaluation plan for the program.

(F) The extent to which services provided under this part will be coordinated with other services available to homeless children and youths and their families.

(G) Such other measures as the State educational agency considers indicative of a high-quality program, such as the extent to which the local educational agency will provide case management or related services to unaccompanied youths.

(4) DURATION OF GRANTS - Grants awarded under this section shall be for terms not to exceed 3 years.

(d) AUTHORIZED ACTIVITIES - A local educational agency may use funds awarded under this section for activities that carry out the purpose of this part, including the following:

(1) The provision of tutoring, supplemental instruction, and enriched educational services that are linked to the achievement of the same challenging State academic content standards and challenging State student academic achievement standards the State establishes for other children and youths.

(2) The provision of expedited evaluations of the strengths and needs of homeless children and youths, including needs and eligibility for programs and services (such as educational programs for gifted and talented students, children with disabilities, and students with limited English proficiency, services provided under title I of the Elementary and Secondary Education Act of 1965 [20 U.S.C. $\underline{6301}$ et seq.] or similar State or local programs, programs in vocational and technical education, and school nutrition programs).

(3) Professional development and other activities for educators and pupil services personnel that are designed to heighten the understanding and sensitivity of such personnel to the needs of homeless children and youths, the rights of such children and youths under this part, and the specific educational needs of runaway and homeless youths.

(4) The provision of referral services to homeless children and youths for medical, dental, mental, and other health services.

(5) The provision of assistance to defray the excess cost of transportation for students under section $11432(\mathrm{~g})(4)(\mathrm{A})$ of this title, not otherwise provided through Federal, State, or local funding, where necessary to enable students to attend the school selected under section $11432(\mathrm{~g})(3)$ of this title.

(6) The provision of developmentally appropriate early childhood education programs, not otherwise provided through Federal, State, or local funding, for preschool-aged homeless children.

(7) The provision of services and assistance to attract, engage, and retain homeless children and youths, and unaccompanied youths, in public school programs and services provided to nonhomeless children and youths.

(8) The provision for homeless children and youths of before- and after-school, mentoring, and summer programs in which a teacher or other qualified individual provides tutoring, homework assistance, and supervision of educational activities. 
(9) If necessary, the payment of fees and other costs associated with tracking, obtaining, and transferring records necessary to enroll homeless children and youths in school, including birth certificates, immunization or medical records, academic records, guardianship records, and evaluations for special programs or services.

(10) The provision of education and training to the parents of homeless children and youths about the rights of, and resources available to, such children and youths.

(11) The development of coordination between schools and agencies providing services to homeless children and youths, as described in section $\underline{11432} \mathrm{~g}$ (g)(5) of this title.

(12) The provision of pupil services (including violence prevention counseling) and referrals for such services.

(13) Activities to address the particular needs of homeless children and youths that may arise from domestic violence.

(14) The adaptation of space and purchase of supplies for any nonschool facilities made available under subsection (a)(2) of this section to provide services under this subsection.

(15) The provision of school supplies, including those supplies to be distributed at shelters or temporary housing facilities, or other appropriate locations.

(16) The provision of other extraordinary or emergency assistance needed to enable homeless children and youths to attend school.

\section{U.S.C. $§ 11434$ - SECRETARIAL RESPONSIBILITIES}

(a) REVIEW OF STATE PLANS - In reviewing the State plan submitted by a State educational agency under section $\underline{11432}(\mathrm{~g})$ of this title, the Secretary shall use a peer review process and shall evaluate whether State laws, policies, and practices described in such plan adequately address the problems of homeless children and youths relating to access to education and placement as described in such plan.

(b) TECHNICAL ASSISTANCE - The Secretary shall provide support and technical assistance to a State educational agency to assist such agency in carrying out its responsibilities under this part, if requested by the State educational agency.

(c) NOTICE - The Secretary shall, before the next school year that begins after January 8,2002 , create and disseminate nationwide a public notice of the educational rights of homeless children and youths and disseminate such notice to other Federal agencies, programs, and grantees, including Head Start grantees, Health Care for the Homeless grantees, Emergency Food and Shelter grantees, and homeless assistance programs administered by the Department of Housing and Urban Development.

(d) EVALUATION AND DISSEMINATION - The Secretary shall conduct evaluation and dissemination activities of programs designed to meet the educational needs of homeless elementary and secondary school students, and may use funds appropriated under section $\underline{11435}$ of this title to conduct such activities.

(e) SUBMISSION AND DISTRIBUTION - The Secretary shall require applications for grants under this part to be submitted to the Secretary not later than the expiration of the 60 -day period beginning on the date that funds are available for purposes of making such 
grants and shall make such grants not later than the expiration of the 120-day period beginning on such date.

(f) DETERMINATION BY SECRETARY - The Secretary, based on the information received from the States and information gathered by the Secretary under subsection $(\mathrm{h})$ of this section, shall determine the extent to which State educational agencies are ensuring that each homeless child and homeless youth has access to a free appropriate public education, as described in section 11431 (1) of this title.

(g) GUIDELINES - The Secretary shall develop, issue, and publish in the Federal Register, not later than 60 days after January 8, 2002, school enrollment guidelines for States with respect to homeless children and youths. The guidelines shall describe-

(1) successful ways in which a State may assist local educational agencies to immediately enroll homeless children and youths in school; and

(2) how a State can review the State's requirements regarding immunization and medical or school records and make such revisions to the requirements as are appropriate and necessary in order to enroll homeless children and youths in school immediately.

\section{(h) INFORMATION}

(1) IN GENERAL - From funds appropriated under section $\underline{11435}$ of this title, the Secretary shall, directly or through grants, contracts, or cooperative agreements, periodically collect and disseminate data and information regarding -

(A) the number and location of homeless children and youths;

(B) the education and related services such children and youths receive;

(C) the extent to which the needs of homeless children and youths are being met; and

(D) such other data and information as the Secretary determines to be necessary and relevant to carry out this part.

(2) COORDINATION - The Secretary shall coordinate such collection and dissemination with other agencies and entities that receive assistance and administer programs under this part.

(i) REPORT - Not later than 4 years after January 8, 2002, the Secretary shall prepare and submit to the President and the Committee on Education and the Workforce of the House of Representatives and the Committee on Health, Education, Labor, and Pensions of the Senate a report on the status of education of homeless children and youths, which shall include information on-

(1) the education of homeless children and youths; and

(2) the actions of the Secretary and the effectiveness of the programs supported under this part.

\section{U.S.C. $\$ 11434 a-$ DEFINITIONS}

For purposes of this part:

(1) The terms "enroll" and "enrollment" include attending classes and participating fully in school activities.

(2) The term "homeless children and youths"- 
(A) means individuals who lack a fixed, regular, and adequate nighttime

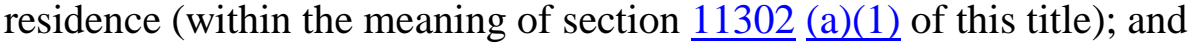
(B) includes-

(i) children and youths who are sharing the housing of other persons due to loss of housing, economic hardship, or a similar reason; are living in motels, hotels, trailer parks, or camping grounds due to the lack of alternative adequate accommodations; are living in emergency or transitional shelters; are abandoned in hospitals; or are awaiting foster care placement; (ii) children and youths who have a primary nighttime residence that is a public or private place not designed for or ordinarily used as a regular sleeping accommodation for human beings (within the meaning of section 11302 (a)(2)(C) $\underline{\text { [1] }}$ of this title); (iii) children and youths who are living in cars, parks, public spaces, abandoned buildings, substandard housing, bus or train stations, or similar settings; and

(iv) migratory children (as such term is defined in section $\underline{6399}$ of title 20) who qualify as homeless for the purposes of this part because the children are living in circumstances described in clauses (i) through (iii).

(3) The terms "local educational agency" and "State educational agency" have the meanings given such terms in section $\underline{7801}$ of title 20 .

(4) The term "Secretary" means the Secretary of Education.

(5) The term "State" means each of the 50 States, the District of Columbia, and the Commonwealth of Puerto Rico.

(6) The term "unaccompanied youth" includes a youth not in the physical custody of a parent or guardian.

\section{U.S.C. $§ 11435$ - AUTHORIZATION OF APPROPRIATIONS}

For the purpose of carrying out this part, there are authorized to be appropriated $\$ 100,000,000$ for fiscal year 2009 and such sums as may be necessary for each subsequent fiscal year. 


\section{APPENDIX B \\ CHRONOLOGICAL LISTING OF LEGISLATION}

1592 statue to oversee "those in economic distress"

1601 Poor Law of 1601, referred to as the Elizabethan Poor Law

1701 colonial treasury reimbursed local funding for relief given to "unsettled persons"

1849 Roberts v. City of Boston, 59 Mass. 198

1865 the Bureau of Refugees, Freedmen, and Abandoned Lands was established by Congress as the first welfare agency

1948 Universal Declaration of Human Rights (UDHR)

1954 Oliver L. Brown et.al. v. the Board of Education of Topeka (KS) et.al., 347 U.S. 483, 74 S.Ct. 686, 98 L.Ed. 873

1965 Elementary and Secondary Education Act of 1965 (ESEA) (P.L. 89-10, 79 Stat. 27, 20 U.S.C. ch. 70)

1972 San Antonio v Rodriquez, 411 U.S. 1, 93 S.Ct. 1278, 36 L.Ed.2d 16

1982 Plyler v Doe, 457 U.S. 202, 102 S.Ct. 2382, 72 L.Ed. 786

1987 Education for Homeless Children and Youth Program (EHCY) as Title VII, Subtitle B of The Stewart B. McKinney Homeless Assistance Act (McKinney Act)

1988 reauthorized

1990 McKinney Act Amended

1992 McKinney Act Amended

1992 Salazar v. Edwards

1994 McKinney Act Amended 
1998 Lampkin v. District of Columbia, 27 F. 3d 605 (D.C. Cir. 1994), cert. denied, 513 U.S. 1016 (1994), on remand, 879 F. Supp. 116 (D.D.C. 1995), dissolving injunction, 886 F. supp. 56 (D.D.C. 1995)

1999 Biggert proposed changes to federal legislation to match Illinois law

2001 It passes as McKinney-Vento Homeless Assistance Act.

2001 No Child Left Behind Act - further assists the federal law.

2002 McKinney-Vento amended

2007 Kaleuati v. Tonda

2009 proposal Senate Bill 2800: Educational Success for Children and Youth Without Homes 2010 Educational Success for Children and Youth Without Homes Act of 2010

2012 Allen and Shaw v. Hoover City Schools

2012 Rhode Island Homeless Person's Bill of Rights

2013 Illinois Homeless Bill of Rights 


\section{APPENDIX C \\ ILLINOIS BILL OF RIGHTS FOR THE HOMELESS}

Public Act 090-0516

SB1210 Enrolled

LRB098 07470 HEP 37540 b

AN ACT in relation to homeless persons.

\section{Be it enacted by the People of the State of Illinois, represented in the General}

\section{Assembly:}

Section 1. Short title. This Act may be cited as the Bill of Rights for the Homeless Act.

Section 5. Legislative intent. It is the long-standing policy of this State that no person should suffer unnecessarily from cold or hunger, be deprived of shelter or the basic rights incident to shelter, or be subject to unfair discrimination based on his or her homeless status. At the present time, many persons have been rendered homeless as a result of economic hardship, a severe shortage of safe and affordable housing, and a shrinking social safety net. It is the intent of this Act to lessen the adverse effects and conditions caused by the lack of residence or a home.

Section 10. Bill of Rights.

(a) No person's rights, privileges, or access to public services may be denied or abridged solely because he or she is homeless. Such a person shall be granted the same rights and privileges as any other citizen of this State. A person experiencing homelessness has the following rights: 
Public Act 090-0516

SB1210 Enrolled

LRB098 07470 HEP 37540 b

(1) the right to use and move freely in public spaces, including but not limited to public sidewalks, public parks, public transportation, and public buildings, in the same manner as any other person and without discrimination on the basis of his or her housing status;

(2) the right to equal treatment by all State and municipal agencies, without discrimination on the basis of housing status;

(3) the right not to face discrimination while maintaining employment due to his or her lack of permanent mailing address, or his or her mailing address being that of a shelter or social service provider;

(4) the right to emergency medical care free from discrimination based on his or her housing status;

(5) the right to vote, register to vote, and receive documentation necessary to prove identity for voting without discrimination due to his or her housing status;

(6) the right to protection from disclosure of his or her records and information provided to homeless shelters and service providers to State, municipal, and private entities without appropriate legal authority; and the right to confidentiality of personal records and information in accordance with all limitations on disclosure established by the federal Homeless

Public Act 090-0516

SB1210 Enrolled

LRB098 07470 HEP 37540 b 
Management Information Systems, the federal Health Insurance Portability and Accountability Act, and the federal Violence Against Women Act; and

(7) the right to a reasonable expectation of privacy in his or her personal property to the same extent as personal property in a permanent residence.

(b) As used in this Act, "housing status" means the status of having or not having a fixed or regular residence, including the status of living on the streets, in a shelter, or in a temporary residence.

Section 15. Damages and attorney's fees. In any civil action alleging a violation of this Act, the court may award appropriate injunctive and declaratory relief, actual damages, and reasonable attorney's fees and costs to a prevailing plaintiff.

Section 99. Effective date. This Act takes effect upon becoming law. 